\title{
Influence of vegetation type and site-to-site variability on soil carbonate clumped isotope records, Andean piedmont of Central Argentina $\left(32-34^{\circ} \mathrm{S}\right)$
}

Mallory C. Ringham ${ }^{*}$, Gregory D. Hoke ${ }^{1}$, Katharine W. Huntington ${ }^{2}$, Julieta N. Aranibar ${ }^{3}$

${ }^{1}$ Earth Sciences, Syracuse University, Syracuse, NY, 13244, *mcringha@ syr.edu

${ }^{2}$ Earth and Space Sciences, University of Washington, Seattle, Washington,

${ }^{3}$ Instituto Argentino de Nivologia, Glaciologia y Ciencias Ambientales, CCT-Mendoza, 5500 Mendoza, Argentina

1

2

\section{Abstract}

The clumped isotope geothermometer estimates the formation temperature $\left(T\left(\Delta_{47}\right)\right)$ of carbonates and has great potential to enhance the extraction of environmental data from

pedogenic (soil) carbonate in the geologic record. However, the influence of vegetation type and site-specific conditions on carbonate formation processes and $\mathrm{T}\left(\Delta_{47}\right)$ records remains poorly understood. This study examines the potential for variability in $T\left(\Delta_{47}\right)$ data between nearby, same elevation sites with different $\mathrm{C}_{3} / \mathrm{C}_{4}$ biomass. Pedogenic carbonates (undercoatings and nodules) were collected from five modern soil pits in the semi-arid eastern Andean piedmont of Argentina under a summer precipitation regime. Three pits were instrumented with temperature and moisture sensors to $1 \mathrm{~m}$ depth, and a fourth was instrumented with additional soil $\mathrm{CO}_{2}$ and atmospheric (temperature, relative humidity, insolation, and rainfall) sensors. $T\left(\Delta_{47}\right)$ values (mean: $\left.30 \pm 6{ }^{\circ} \mathrm{C}( \pm 1 \mathrm{SE})\right)$ are invariant with depth and are statistically indistinguishable between the four instrumented sites, though a $10{ }^{\circ} \mathrm{C}$ difference between our $\mathrm{T}\left(\Delta_{47}\right)$ values and those of a nearby Peters et al. (2013, EPSL) study suggests the potential for significant site-tosite variability, likely due to local soil hydrology. The results of this study suggest that deeper $(\geq$ $40 \mathrm{~cm}) \mathrm{T}\left(\Delta_{47}\right)$ values are consistent with carbonate formation during the early part of soil drying immediately after large mid-summer rainstorms. Carbonate formation $\leq 40 \mathrm{~cm}$ depth may be biased to soil drying after small, frequent precipitation events occurring throughout the spring, summer, and fall months, averaging to shallow summer $\mathrm{T}\left(\Delta_{47}\right)$ values and resulting in a nearisothermal $\mathrm{T}\left(\Delta_{47}\right)$ profile. 


\section{Introduction}

The development of low temperature geothermometers is important to researchers studying Earth surface processes, paleoaltimetry, and paleoclimate. The clumped isotope

25 geothermometer allows for the determination of near-surface temperatures based on the relative degree of ${ }^{13} \mathrm{C}-{ }^{18} \mathrm{O}$ bonding in carbonates $\left(\mathrm{CaCO}_{3}\right)$. "Clumping" of these heavy isotopes varies

27 inversely with temperature, providing an estimate of carbonate formation temperature $\left(\mathrm{T}\left(\Delta_{47}\right)\right.$, where $\Delta_{47}$ refers the abundance of ${ }^{13} \mathrm{C}-{ }^{18} \mathrm{O}$ bonds in $\mathrm{CO}_{2}$ gas derived from carbonate in excess of a stochastic distribution) that is independent of bulk isotopic composition (Ghosh et al. 2006a;

30 Eiler, 2007). Thus, clumped isotope thermometry solves the issue of two unknowns in

31 conventional stable isotope analysis of carbonate, in which carbonate $\delta^{18} \mathrm{O}$ depends on both the

32 temperature of mineral formation and the oxygen isotopic composition of the soil water.

Early uses of clumped isotope geothermometry assumed that pedogenic carbonate

34 formation temperatures reflect mean annual soil temperatures (MAST), with potential systematic errors due to seasonal biases (e.g. Ghosh et al., 2006b). Breecker et al. (2009) calculated a strong seasonal bias for carbonate formation during warm, drying episodes in the soil when soil $\mathrm{pCO}_{2}$ is

37 low. Several studies have found $\mathrm{T}\left(\Delta_{47}\right)$ to be far in excess of MAST (e.g. Passey et al. 2010;

38 Quade et al. 2013; Hough et al. 2014) or to reflect a mixture of summer and fall temperatures 39 depending on the timing of the wet season and snowmelt (Peters et al. 2013). Depth-resolved $40 \mathrm{~T}\left(\Delta_{47}\right)$ data are reported in Passey et al. (2010), Quade et al. (2013), and Peters et al. (2013), and 41 nearly all published $\mathrm{T}\left(\Delta_{47}\right)$ profiles are isothermal with depth. Quade et al. (2013) interpreted 42 their $\mathrm{T}\left(\Delta_{47}\right)$ data as decreasing with depth, following the pattern for summer soil temperatures; 43 however, with consideration of the typical $4-6{ }^{\circ} \mathrm{C}$ uncertainty in clumped isotope methods, these 44 data appear to be isothermal. Peters et al. (2013) observed no systematic decrease in $T\left(\Delta_{47}\right)$ with 
45 depth, which was consistent with typical fall soil temperatures. Together these data call into

46 question our collective understanding of carbonate formation in the soil profile, such that

47 summer biases for $\mathrm{T}\left(\Delta_{47}\right)$ are generally accepted, though $\mathrm{T}\left(\Delta_{47}\right)$ with depth and the timing of

48 carbonate precipitation in soil require clarification.

This study examines the potential for variability of $\mathrm{T}\left(\Delta_{47}\right)$ data from soil carbonate

50 nodules and undercoatings collected in the Andean piedmont of Argentina (32.5-34 ${ }^{\circ}$; Figure 1$)$

51 in order to better constrain the conditions that lead to carbonate precipitation and to improve

52 interpretations of clumped isotope paleoenvironmental records. We simplified our investigation

53 by (1) choosing sites in a summer-only precipitation regime, thereby limiting variability in

54 seasonal soil drying, (2) varying $\mathrm{C}_{4} / \mathrm{C}_{3}$ biomass, which may bias seasonal soil moisture and $\mathrm{CO}_{2}$

55 conditions during times of peak productivity, and (3) comparing same elevation nearby sites, as

56 some studies show a strong correlation between $\mathrm{T}\left(\Delta_{47}\right)$ and elevation (Quade et al 2013; Hough

57 et al. 2014) while others do not (Peters et al. 2013). Our objectives are to explore the influence of

58 environmental variables on the timing of pedogenic carbonate formation via in-situ monitoring

59 of atmospheric conditions, soil temperature, soil moisture, soil gas $\mathrm{CO}_{2}$ concentration, and

60 vegetation type, and to determine the potential for site-to-site variability in resulting $\mathrm{T}\left(\Delta_{47}\right)$

61 values.

62

63 2. Background

642.1 Controls on pedogenic carbonate formation

65 Pedogenic carbonate forms over hundreds to thousands of years as filaments, root casts, 66 nodules, clast undercoatings, or horizons in sub-humid to arid soils when the soil solution 
67 becomes supersaturated with calcite (Gile et al. 1966; Cerling and Quade, 1993). The carbonate

68 formation reaction,

$$
\mathrm{CaCO}_{3(s)}+\mathrm{CO}_{2_{(g)}}+\mathrm{H}_{2} \mathrm{O} \leftrightarrow \mathrm{Ca}_{(a q)}^{2+}+2 \mathrm{HCO}_{3_{(a q)}}^{-}
$$

70

71

72

73

74

75

76

77

78

79

80

81

82

and its corresponding activity equation under aqueous conditions,

$$
\alpha_{\mathrm{CaCO}_{3}}=\frac{4 m_{\mathrm{Ca}^{2+}}^{3}}{p \mathrm{CO}_{2}}\left(\frac{K_{2}}{K_{1} K_{C a l} K_{\mathrm{CO}_{2}}}\right)
$$

show that carbonate precipitation in soils may result from increasing soil temperature, decreasing soil gas $\mathrm{pCO}_{2}$, or increasing $\mathrm{Ca}^{2+}$ or $\mathrm{HCO}_{3}{ }^{-}$concentration in solution (Breecker et al., 2009). In well-drained, arid climate soils, carbonate should form during periods of soil dewatering due to evaporation, root uptake, and decreasing $\mathrm{pCO}_{2}$ (Huxman et al. 2004; Liu et al. 2002). Soil $\mathrm{CO}_{2}$ is an admixture of atmospheric $\mathrm{CO}_{2}$ and biologically respired $\mathrm{CO}_{2}$. Typically, pedogenic carbonate $\delta^{13} \mathrm{C}$ in a soil profile exhibits a positive shift near the surface reflecting a decrease in the respired component of soil $\mathrm{CO}_{2}$ (Luo and Zhou, 2006; Cerling and Quade, 1993). $\delta^{18} \mathrm{O}_{\text {carbonate }}$ depends on $\delta^{18} \mathrm{O}_{\text {soil water (SW) }}$ and temperature-dependent fractionation during carbonate formation. In welldrained soils, $\delta^{18} \mathrm{O}_{\mathrm{SW}}$ is commonly assumed to reflect meteoric water, and is typically enriched near the surface by evaporation (e.g. Cerling and Quade, 1993). In equation 2, $\mathrm{pCO}_{2}$ is the partial pressure of soil gas carbon dioxide, $m_{\mathrm{Ca}^{2+}}$ is the soil solution calcium ion concentration (provided by rainwater and dissolution of Ca-bearing minerals in dust or soil parent material, e.g., Gile et al. 1966; Machette, 1985), and K values are temperature-sensitive equilibrium constants (Drever 1982; Plummer and Busenberg, 1982). A value of alpha $\left(\alpha_{\mathrm{CaCO}_{3}}\right)>1$ indicates precipitation of $\mathrm{CaCO}_{3}$. This equation is valid for systems in thermodynamic equilibrium where activity $\approx$ concentration and soil water $\mathrm{pH} \leq 9$. Recent studies have suggested that isotopic equilibrium in carbonate formation is not always achieved (Gabitov et al., 2012) due to kinetic isotopic effects that may result in increased apparent $\mathrm{T}\left(\Delta_{47}\right)$ values (Guo 2008). However, most 
studies of soils assume that pedogenic carbonate forms in isotopic equilibrium with soil $\mathrm{CO}_{2}$ and soil water during drying episodes (Breecker et al. 2009; Cerling and Quade, 1993).

Recent studies have combined soil carbonate clumped isotope thermometry with in-situ soil monitoring to investigate how these factors affect carbonate formation and $\mathrm{T}\left(\Delta_{47}\right)$ records; most published data suggest a summer temperature bias in carbonate formation, but soil moisture balance may be more important. Quade et al. (2013) found that average T $\left(\Delta_{47}\right)$ measurements of modern soil and paleosol carbonates from soils typically developed under summer rainfall seasonality reflected the hottest months of the year when the soil was dry, exceeding the mean annual air temperature (MAAT) by $10-15^{\circ} \mathrm{C}$. Passey et al. (2010) found that temperatures recorded by modern soil carbonates in temperate latitudes exceeded present-day MAST, plotting closely with average summer soil temperatures. Peters et al. (2013) investigated carbonate formation temperatures along an Andes elevation transect at $\sim 33^{\circ} \mathrm{S}$ and found that average $\mathrm{T}\left(\Delta_{47}\right)$ values for carbonates collected above $2 \mathrm{~km}$ elevation reflect summer soil temperatures, while those below $2 \mathrm{~km}$ more closely reflect MAST. This transition coincides with a change in seasonality of precipitation. This study suggested that below $2 \mathrm{~km}$, summer rainfall delays soil drying until fall, allowing carbonate formation later in the year to record cooler $\mathrm{T}\left(\Delta_{47}\right)$ values. Above $2 \mathrm{~km}$, under winter precipitation, soil dries during the warmest months, allowing for carbonate formation with summer $\mathrm{T}\left(\Delta_{47}\right)$.

Few studies have investigated the behavior of T $\left(\Delta_{47}\right)$ with depth. Quade et al. (2013) reported decreasing $T\left(\Delta_{47}\right)$ with depth, attributed to summer soil temperatures intensified by radiative heating at the surface; however, these profiles do not vary with depth if considered with typical $4-6{ }^{\circ} \mathrm{C}$ uncertainties. Peters et al. (2013) reported isothermal profiles that could be attributed to soil heterogeneity or to higher frequency of carbonate formation at the surface than 
113 at depth, such that if carbonate formation at depth occurs rarely, in response to abnormally hot 114 conditions, $\mathrm{T}\left(\Delta_{47}\right)$ will be more constant throughout the soil profile.

The type and amount of vegetation in a region may also influence the timing of carbonate

116 formation because plants impact radiative heating at the soil surface and focus removal of

117 moisture within the rooted part of the soil profile. $\mathrm{C}_{3}$ and $\mathrm{C}_{4}$ type plants are adapted to different

118 levels of $\mathrm{CO}_{2}$, light intensity, and water stress due to variations in metabolic pathways for

119 photosynthetic carbon fixation. $\mathrm{C}_{3}$ plants are adapted for productivity under moderate soil and air

120 temperatures and light intensities, and are most active during spring and fall in arid

121 environments. However, $\mathrm{C}_{3}$ plants may be active when water is available during the warmest

122 summer months, in spite of high temperatures, due to stomatal regulation, solar tracking, leaflet

123 closure, low leaf area index, photosynthetic stems, leaf waxes, and varying root profiles that

124 maximize water uptake after precipitation events (Villagra et al., 2011; Giordano et al., 2011;

125 Guevara et al., 2010; Meglioli et al., 2015). $\mathrm{C}_{4}$ plants, including most grasses in arid regions, are 126 generally adapted to high water and temperature stress and low $\mathrm{pCO}_{2}$, enhancing soil dewatering

127 during summer, so it is expected that carbonate $\mathrm{T}\left(\Delta_{47}\right)$ values will be high in regions of high

128 ratios of $\mathrm{C}_{4}$ to $\mathrm{C}_{3}$ plant biomass (Breecker et al. 2009; Meyer et al. 2014). If vegetation type

129 influences site-to-site variability in $\mathrm{T}\left(\Delta_{47}\right)$ records, paleoenvironmental interpretations of

130 formation temperatures may be significantly complicated, as $\mathrm{C}_{4} / \mathrm{C}_{3}$ distribution may be altered 131 by changes in elevation, climate, and land use over time.

\subsection{General sampling site description}

We sampled pedogenic carbonate from the eastern Andean piedmont of Argentina at 32-

$13534{ }^{\circ} \mathrm{S}$ in the Villavicencio (CAN01, CAN02), Divisadero Largo (DL01), and Nacuñan Nature 
Reserves (Figure 1). The piedmont is an arid, gently eastward sloping topographic feature; the western edge borders the Andes at $~ 1000 \mathrm{~m}$ elevation, sloping down to $\sim 500 \mathrm{~m}$ at the eastern edge. The entire piedmont experiences spatially discontinuous summer convective precipitation with infrequent westerly precipitation events rarely reaching its western edge during winter (Mancini et al., 2005). MAAT recorded at Mendoza ( $\sim 830 \mathrm{~m}$ elevation) is $\sim 17^{\circ} \mathrm{C}$ and mean annual precipitation (MAP) is $\sim 220 \mathrm{~mm}$ (1989-2015) (Base de Datos Hidrológica Integrada (BDHI, http://bdhi.hidricosargentina.gov.ar) and Servicio Meteorológico Nacional (SMN, http://www.smn.gov.ar)). Vegetation type and cover density across the piedmont trend from a nearly $50 / 50 \mathrm{C}_{4} / \mathrm{C}_{3}$ grass mixture at $1000 \mathrm{~m}$ elevation in the west to a $90 / 10$ grass mixture at 600 $\mathrm{m}$ in the east, with size and density of shrubs and trees increasing to the east (Cavagnaro, 1988). Soils of the western piedmont are developed in a coarse-grained alluvial conglomerate parent material and contain stage I/II carbonate development (continuous clast undercoatings) (Gile et al. 1966; Birkeland, 1999). Cosmogenic nuclide dating of tectonically uplifted terraces in the otherwise contiguous piedmont between Villavicencio and Mendoza yield ages between 21 and $0.7 \mathrm{ka}$, highest to lowest, respectively (Schmidt et al., 2011). Our soil pits are adjacent to these terraces but not tectonically disturbed, thus we suggest that surface ages are $<5000$ years.

The Nacuñan Nature Reserve is located $\sim 150 \mathrm{~km}$ to the southeast of Mendoza at $34{ }^{\circ} \mathrm{S}$. This region also experiences summer-only precipitation, with MAAT $\sim 16^{\circ} \mathrm{C}$ and MAP $\sim 326$ mm (Ojeda et al. 1998). Plant productivity here is higher than at the Villavicencio and Divisadero Largo sites, although the total $\mathrm{C}_{4} / \mathrm{C}_{3}$ distribution (grasses and shrubs) is similar to Villavicencio. The soil is modern, based on radiocarbon dating of carbonate nodule samples (Section 3.1), and consists of medium- to coarse-grained sand that contains carbonate nodules. 
valley) provides context for our study, including documentation of the elevation dependence of $\delta^{18} \mathrm{O}$ values in precipitation, river water, and pedogenic carbonate (e.g. Hoke et al. 2009; 2013),

161 and associated soil carbonate clumped isotope records (e.g. Peters et al. 2013). Data from the 2

162 nearest Peters et al. (2013) sites are provided for comparison with our results (Figures 1,3-4).
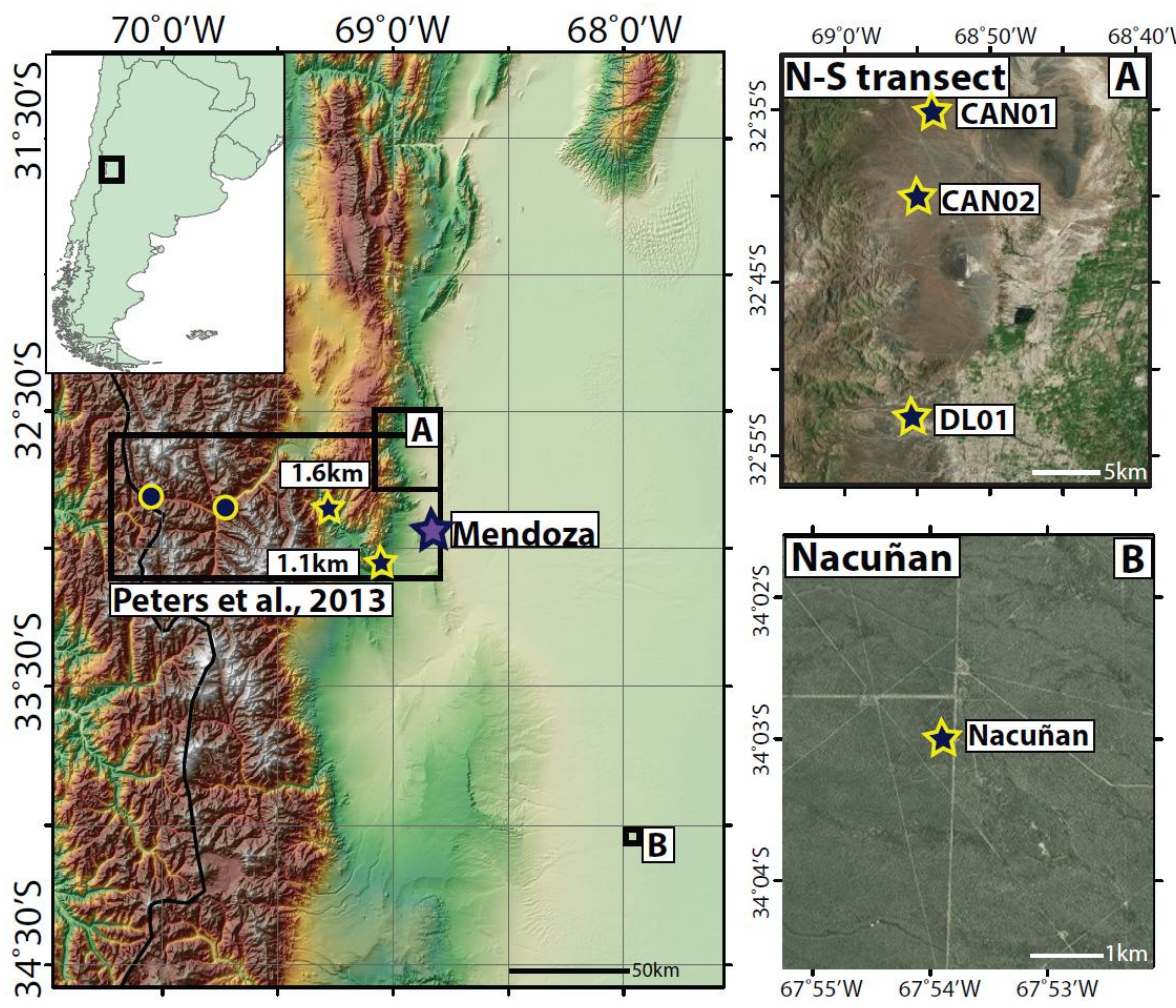

Figure 1:

Eastern Andean piedmont of central Argentina, $\sim 32-34{ }^{\circ} \mathrm{S}$.

Left: Peters et al. (2013) transect with subsurface monitoring sites at $3.2 \mathrm{~km}, 2.4 \mathrm{~km}$ (circles, not considered in this study), $1.6 \mathrm{~km}$ and $1.1 \mathrm{~km}$ (stars).

Right: Inset A: locations (stars) of CAN01, CAN02, and DL01 subsurface monitoring sites. Inset B: location of Nacuñan Nature Reserve site.

\section{Methods}

\subsection{Field station characterization and sampling}

In order to investigate the impact of local factors on soil carbonate growth and $\mathrm{T}\left(\Delta_{47}\right)$, we collected modern soil carbonates for $\mathrm{T}\left(\Delta_{47}\right)$ and ${ }^{14} \mathrm{C}$ analysis as well as in-situ field data on subsurface conditions (soil temperature, moisture, $\mathrm{pCO}_{2}$, rooting depth, substrate, carbonate stage), meteorological conditions (air temperature, rainfall, relative humidity, insolation) and vegetation. In July 2013, four soil pits were excavated over a $\sim 40 \mathrm{~km} \mathrm{~N}-\mathrm{S}$ transect between the 
192 Villavicencio and Divisadero Largo Nature Reserves $\left(\sim 32.7^{\circ} \mathrm{S}\right)$ (Figure 1, Table 1). Two pits

193 (CAN01 and CAN02), separated by $\sim 6 \mathrm{~km}$, were instrumented with Onset soil temperature

194 sensors $(10,50$, and $100 \mathrm{~cm})$ and moisture sensors $(50 \mathrm{~cm})$ connected to an Onset microstation

195 data logger (Figure 2a). A pendant temperature logger mounted in a radiation shield was

196 suspended from a pole at $1.5 \mathrm{~m}$ above the ground surface. A third pit (DL01) was instrumented

197 with soil temperature and moisture sensors at 10 and $50 \mathrm{~cm}$ depth. Stage I-II pedogenic

198 carbonate undercoatings on non-carbonate clasts were collected from these sites at $15-20 \mathrm{~cm}$

199 intervals to $1 \mathrm{~m}$ depth. The fourth pit (CAN03) was sampled for carbonate undercoatings at 50

$200 \mathrm{~cm}$ depth. The substrate for each soil pit was cobble to boulder conglomerate. A fifth pit was

201 sampled for carbonate nodules to $1 \mathrm{~m}$ depth in the Nacuñan Nature Reserve $\left(\sim 34{ }^{\circ} \mathrm{S}\right.$; Figure 1 ,

202 Table 1). This pit was instrumented with Onset soil moisture and temperature sensors at 10, 50,

203 and $100 \mathrm{~cm}$ depth, a Vaisala $\mathrm{pCO}_{2}$ sensor at $50 \mathrm{~cm}$ depth, and Onset air temperature, relative

204 humidity, insolation, and rain sensors (Figure 2b). Readings from all instruments were logged at

205 15-minute intervals by an Onset U30-NRC logger (July 2013- May 2015); all sensors were tested

206 prior to deployment in the field for proper functionality, and resulting data were calibrated

207 according to the sensor manufacturer. Vegetation estimates of biomass as \% cover were collected

208 using point intercept surveys conducted in representative, undisturbed areas near each soil pit at

209 the end of the in-situ monitoring study in April- May 2015.

210 We complemented our in-situ observations with data from nearby weather stations. Daily

211 precipitation data are available from BDHI for Mendoza Airport (near CAN01 and CAN02) and

212 for San Rafael (<100 km southwest of Nacuñan). Daily air temperature and precipitation data are

213 available from NOAA's National Climatic Data Center (NCDC) (http://www.ncdc.noaa.gov/) at

214 Mendoza Airport and Mendoza Observatory. Limited daily air temperature, precipitation, and $\delta \mathrm{D}$ 
215 and $\delta^{18} \mathrm{O}$ data are available from Hoke et al. (2013) and for Mendoza Observatory and Nacuñan

216 through the Global Network of Isotopes in Precipitations (GNIP)

217 (http://www.naweb.iaea.org/napc/ih/IHS_resources_gnip.html).

218 
Table 1: Soil pit and meteorological station locations

\begin{tabular}{|c|c|c|c|c|}
\hline Soil pit site: & \multicolumn{2}{|c|}{ Location } & Elevation & Data available \\
\hline & Latitude (S) & Longitude (W) & (m) & \\
\hline CAN01 & $32^{\circ} 35^{\prime} 31^{\prime \prime}$ & $68^{\circ} 54^{\prime} 19^{\prime \prime}$ & $\sim 1000$ & $\begin{array}{l}\text { Soil T }(10,50,100 \mathrm{~cm}) \text {, Soil Moisture }(50 \mathrm{~cm}) \text {, } \\
\text { Carbonate undercoatings collected to } 1 \mathrm{~m} \text { depth }\end{array}$ \\
\hline CAN02 & $32^{\circ} 39^{\prime} 07^{\prime \prime}$ & $68^{\circ} 55^{\prime} 00^{\prime \prime}$ & $\sim \sim 1000$ & $\begin{array}{l}\text { Soil T }(10,50,100 \mathrm{~cm}), \text { Soil Moisture }(50 \mathrm{~cm}) \\
\text { Carbonate undercoatings collected to } 1 \mathrm{~m} \text { depth }\end{array}$ \\
\hline CAN03 & $32^{\circ} 34^{\prime} 12^{\prime \prime}$ & $68^{\circ} 56^{\prime} 34^{\prime \prime}$ & $\sim 1000$ & $\begin{array}{l}\text { No instrumental data, } \\
\text { Carbonate undercoatings collected at } 50 \mathrm{~cm} \text { depth }\end{array}$ \\
\hline DL01 & $32^{\circ} 52^{\prime} 40^{\prime \prime}$ & $68^{\circ} 55^{\prime} 21^{\prime \prime}$ & $\sim 1000$ & $\begin{array}{l}\text { Soil T }(10,50 \mathrm{~cm}), \text { Soil Moisture }(10,50 \mathrm{~cm}) \\
\text { Carbonate undercoatings collected to } 1 \mathrm{~m} \text { depth }\end{array}$ \\
\hline Nacuñan & $34^{\circ} 02^{\prime} 60^{\prime \prime}$ & $67^{\circ} 54^{\prime} 10^{\prime \prime}$ & $\sim 540$ & $\begin{array}{l}\text { Soil T }(10,50,100 \mathrm{~cm}), \text { Soil Moisture }(10,50,100 \\
\mathrm{cm}), \mathrm{CO}_{2}(50 \mathrm{~cm}) \text {, Air T, Precip., Insolation, } \\
\text { Carbonate nodules collected to } 1 \mathrm{~m} \text { depth }\end{array}$ \\
\hline $\begin{array}{l}\text { Peters et al. } 2013 \\
(1.1 \mathrm{~km})\end{array}$ & $33^{\circ} 02^{\prime} 38^{\prime \prime}$ & $69^{\circ} 00^{\prime} 33^{\prime \prime}$ & $\sim 1100$ & $\begin{array}{l}\text { Soil T }(10,50,100 \mathrm{~cm}) \text {, Soil Moisture }(50 \mathrm{~cm}) \text {, } \\
\text { Carbonate undercoatings collected to } 1 \mathrm{~m} \text { depth }\end{array}$ \\
\hline $\begin{array}{l}\text { Peters et al. } 2013 \\
(1.6 \mathrm{k})\end{array}$ & $32^{\circ} 49^{\prime} 24^{\prime \prime}$ & $69^{\circ} 17^{\prime} 55^{\prime \prime}$ & $\sim 1600$ & $\begin{array}{l}\text { Soil T }(10,50,100 \mathrm{~cm}) \text {, Soil Moisture }(50 \mathrm{~cm}) \text {, } \\
\text { Carbonate undercoatings collected to } 1 \mathrm{~m} \text { depth }\end{array}$ \\
\hline $\begin{array}{l}\text { Meteorological } \\
\text { station: }\end{array}$ & Latitude (S) & Longitude (W) & Elevation & Data available \\
\hline BDHI: Mendoza & $33^{\circ} 00^{\prime} 54^{\prime \prime}$ & $69^{\circ} 07^{\prime} 03^{\prime \prime}$ & $\begin{array}{ll} & 1000\end{array}$ & Precip. (1983-2015) \\
\hline $\begin{array}{l}\text { NCDC: Mendoza } \\
\text { Airport }\end{array}$ & $32^{\circ} 49^{\prime} 59^{\prime \prime}$ & $68^{\circ} 46^{\prime} 59^{\prime \prime}$ & $\sim 1000$ & Air T, precip. (1959-2015) \\
\hline $\begin{array}{l}\text { NCDC: Mendoza } \\
\text { Observatory }\end{array}$ & $32^{\circ} 53^{\prime} 00^{\prime \prime}$ & $68^{\circ} 51^{\prime} 00^{\prime \prime}$ & $\sim 1000$ & Air T, precip. (1959-2015) \\
\hline $\begin{array}{l}\text { GNIP: Mendoza } \\
\text { Observatory }\end{array}$ & $32^{\circ} 52^{\prime} 48^{\prime \prime}$ & $68^{\circ} 51^{\prime} 00^{\prime \prime}$ & $\sim 1000$ & Air T, precip., $\delta \mathrm{D}, \delta^{18} \mathrm{O}(1982-1988,1998-1999)$ \\
\hline GNIP: Nacuñan & $34^{\circ} 01^{\prime} 48^{\prime \prime}$ & $67^{\circ} 58^{\prime} 12^{\prime \prime}$ & $\sim 540$ & Air T, precip., $\delta \mathrm{D}, \delta^{18} \mathrm{O}(1982-1984)$ \\
\hline BDHI: San Rafael & $34^{\circ} 36^{\prime} 44^{\prime \prime}$ & $68^{\circ} 18^{\prime} 58^{\prime \prime}$ & $\sim 1000$ & Precip. (1984-2014) \\
\hline
\end{tabular}
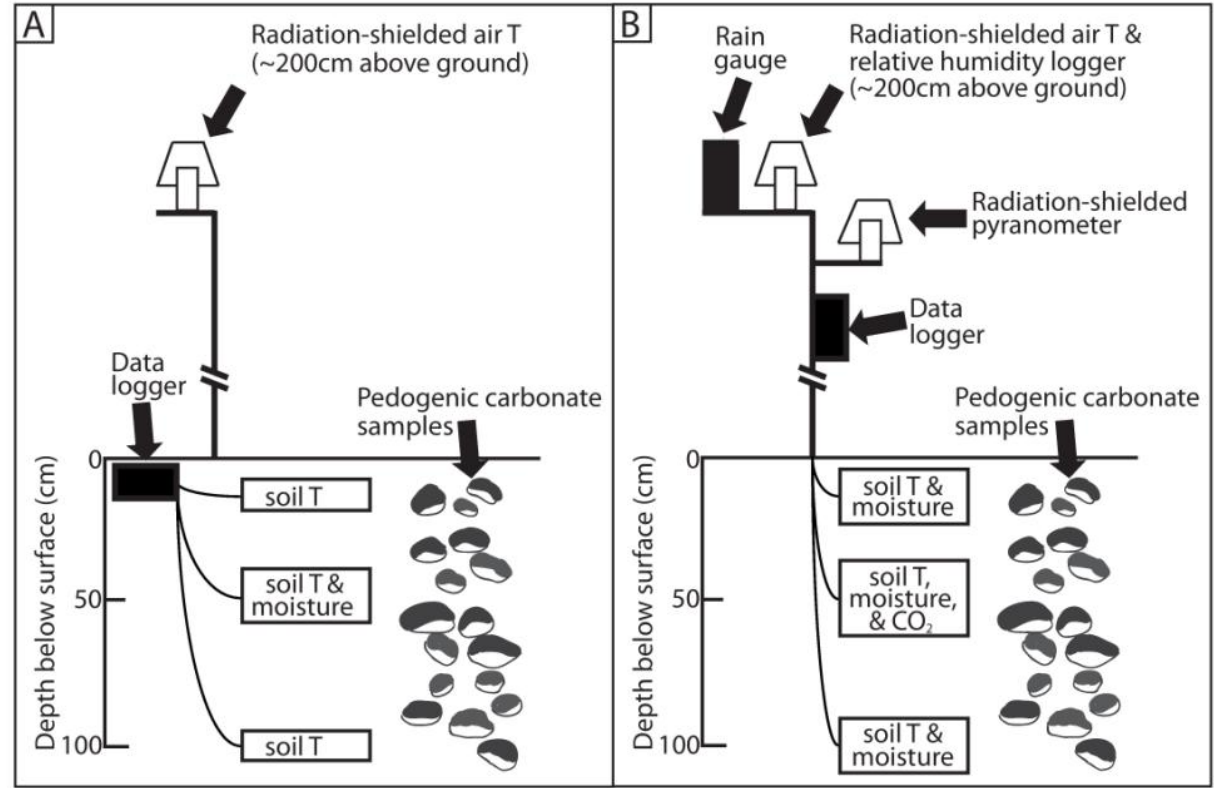

Figure 2: (a) CAN01 and CAN02 site sensor instrumentation (from Peters et al. 2013) (b) Nacuñan soil and atmospheric sensor instrumentation. 


\subsection{Stable isotopic analysis and radiocarbon dating methods}

Carbonate undercoatings from the piedmont soils were scraped from multiple noncarbonate clasts of the same depth, powdered, and homogenized with an agate mortar and pestle. Carbonate nodules from the sandy soil at Nacuñan were crushed and homogenized, with care taken to remove roots and obvious organic material.

The samples were analyzed at the University of Washington's IsoLab in December 2013 and July 2014. Carbonate samples and standards (8 mg calcite) were digested in $105 \%$ phosphoric acid at $90{ }^{\circ} \mathrm{C}$ with the evolved $\mathrm{CO}_{2}$ gas purified using an automated stainless steel vacuum line. The $\mathrm{CO}_{2}$ was analyzed on a Thermo MAT 253 mass spectrometer configured to measure $\mathrm{m} / \mathrm{z}$ 44-49 inclusive. Values of $\delta^{13} \mathrm{C}, \delta^{18} \mathrm{O}, \Delta_{47}$, and $\Delta_{48}$ were calculated using established methods (Eiler and Schauble, 2004; Affek and Eiler, 2006; Huntington et al., 2009 and references therein), with $\Delta_{47}$ values corrected to the Absolute Reference Frame (ARF) of Dennis et al. (2011) using heated gas $\left(1000^{\circ} \mathrm{C}\right)$ and $\mathrm{CO}_{2}$-water equilibration $\left(4\right.$ and $\left.60{ }^{\circ} \mathrm{C}\right)$ lines constructed during the analysis period. Samples with $\Delta_{48}$ values higher than $2 \%$, indicating contamination, were rejected. Select samples were also analyzed for $\delta^{13} \mathrm{C}$ and $\delta^{18} \mathrm{O}$ using a Kiel III carbonate device coupled to a Thermo-Finnigan Delta Plus isotope ratio mass spectrometer (noted in Table 3), following the methods of Tobin et al. (2011).

$\mathrm{T}\left(\Delta_{47}\right)$ values were calculated using the synthetic carbonate calibration of Kluge et al. (2015), which was developed using analytical methods similar to our own (e.g. acid digestion at $90{ }^{\circ} \mathrm{C}$ ), as well as that of Zaarur et al. (2013) (e.g. acid digestion at $25^{\circ} \mathrm{C}$ ), for reference. For the range of $\Delta_{47}$ values reported in this study (0.572-0.639\%, Table 3), the two calibrations result in similar $\mathrm{T}\left(\Delta_{47}\right)$ estimates, differing by an average of $6 \%\left(\sim 2{ }^{\circ} \mathrm{C}\right)$ for samples with $\mathrm{n}=3$ 
245 replicates. $T\left(\Delta_{47}\right)$ values from samples with $n=3$ replicates are generally recorded to $4-6{ }^{\circ} \mathrm{C}$ 246 precision (1 SE).

247 The $\Delta_{47}$ data for soil carbonates from nearby sites by Peters et al. (2013) were reported 248 relative to heated gases only and are not directly comparable to data reported in the ARF. To 249 facilitate direct comparison of the Peters et al. (2013) dataset with the results of this study, splits 250 of their same $50 \mathrm{~cm}$ depth samples (1.1 and $1.6 \mathrm{~km}$ sites) were reanalyzed at the University of 251 Washington in April 2015. Radiocarbon dating was performed by DirectAMS (www.directams.com). Pedogenic 253 carbonate samples were digested in phosphoric acid under vacuum to produce $\mathrm{CO}_{2}$. A disposable 254 manifold was used to transfer the $\mathrm{CO}_{2}$ to an individual reaction vessel containing zinc and an 255 inner vial of iron dust, which was heated at $550{ }^{\circ} \mathrm{C}$ for $\sim 5$ hours to form graphite. Samples were 256 analyzed on a National Electrostatics Corporation 1.55DH-1 Pelletron Accelerator (0.3\% 257 precision and accuracy).

\section{Results}

\subsection{Vegetation survey, radiocarbon ages, and in-situ soil monitoring results}

262 with a $\mathrm{C}_{4}$ grass layer (Table 2). DL01 is dominated by $\mathrm{C}_{3}$ grasses and shrubs with a higher plant 263 cover than the CAN sites, which may be due to the slight southern aspect of this terrace, which 264 receives lower irradiance than the more exposed CAN sites. Nacuñan lies in a mixed $\mathrm{C}_{4} / \mathrm{C}_{3}$ 265 environment with the highest productivity of the four sites, including a dominantly $\mathrm{C}_{4}$ grass layer 266 and a high density of $\mathrm{C}_{3}$ shrubs. 
Table 2: Vegetation description with biomass estimated by $\%$ cover

\begin{tabular}{|c|c|c|c|c|}
\hline & CAN01 & CAN02 & DL01 & Nacuñan \\
\hline$\%$ bare soil & 25 & 22 & 3 & 0 \\
\hline $\mathrm{C}_{4} / \mathrm{C}_{3}$ grasses & 4.80 & 36.00 & 0.10 & 2.80 \\
\hline $\begin{array}{l}\mathrm{C}_{4} / \text { total } \\
\text { vegetation cover }\end{array}$ & 0.32 & 0.46 & 0.02 & 0.42 \\
\hline $\begin{array}{l}\text { Dominant grasses } \\
\left(\mathrm{C}_{3} \text { or } \mathrm{C}_{4}\right)\end{array}$ & $\begin{array}{l}\text { - Pappophorum }\left(\mathrm{C}_{4}\right) \\
\text { - Bouteloa barbata }\left(\mathrm{C}_{4}\right) \\
\text {-Eragrostis }\left(\mathrm{C}_{4}\right)\end{array}$ & $\begin{array}{l}\text { - Pappophorum }\left(\mathrm{C}_{4}\right) \\
\text { - Bouteloa barbata }\left(\mathrm{C}_{4}\right) \\
\text {-Eragrostis }\left(\mathrm{C}_{4}\right)\end{array}$ & $\begin{array}{l}\text {-Jarava ichu (formerly } \\
\text { Stipa ichu) }\left(\mathrm{C}_{3}\right)\end{array}$ & $\begin{array}{l}\text { - Pappophorum } \\
\text { caespitosum }\left(\mathrm{C}_{4}\right) \\
\text { - Trichloris crinita }\left(\mathrm{C}_{4}\right) \\
\text { - Setaria mendocina }\left(\mathrm{C}_{4}\right) \\
\text { - Jarava ichu }(\text { formerly } \\
\text { Stipa ichu) }\left(\mathrm{C}_{3}\right) \\
\end{array}$ \\
\hline $\begin{array}{l}\text { Dominant CAM } \\
\text { (cacti) }\left(\mathrm{C}_{4}\right)\end{array}$ & $\begin{array}{l}\text { - Opuntia }\left(\mathrm{C}_{4}\right) \\
\text { - Tephrocactus }\left(\mathrm{C}_{4}\right)\end{array}$ & $\begin{array}{l}\text { - Opuntia }\left(\mathrm{C}_{4}\right) \\
\text { - Tephrocactus }\left(\mathrm{C}_{4}\right)\end{array}$ & & \\
\hline $\begin{array}{l}\text { Dominant shrubs } \\
\left(\mathrm{C}_{3}\right)\end{array}$ & $\begin{array}{l}\text { - Lycium tenuispinosum } \\
\text { - Larrea cuneifolia } \\
\text {-Zucagnia punctata }\end{array}$ & $\begin{array}{l}\text { - Lycium tenuispinosum } \\
\text { - Larrea cuneifolia } \\
\text {-Zucagnia punctata }\end{array}$ & $\begin{array}{l}\text { - Trycicla spinosa } \\
\text { - Lycium tenuispinosum } \\
\text {-Verbena aspera }\end{array}$ & $\begin{array}{l}\text { - Larrea cuneifolia } \\
\text { - Larrea divaricata } \\
\text { - Lycium tenuispinosum } \\
\text { - Prodopsis flexuosa } \\
\text { - Geoffroea decorticans }\end{array}$ \\
\hline
\end{tabular}

269

Radiocarbon dating of pedogenic carbonate undercoatings collected at $40 \mathrm{~cm}$ depth at DL01 produced an age of $2080 \pm 30(1 \sigma)$ years BP, and nodules collected at 30, 50, and $100 \mathrm{~cm}$ depth at Nacuñan produced ages of $5900 \pm 30,11140 \pm 40$, and $16200 \pm 70$ years BP, respectively, indicating Late Pleistocene to present carbonate formation.

At least 1.5 years of data at 15 minute intervals are available for each instrumented soil pit, beginning in July 2013. We report air temperature data for CAN01, CAN02, and Nacuñan. Nacuñan soil $\mathrm{pCO}_{2}$ is available from mid-February 2014 through May 2015; missing data prior to February 2014 was due to a blown fuse in the $\mathrm{CO}_{2}$ sensor solar power system. Other minor gaps in data collection stem from dead batteries (CAN01), micrologger leaks (CAN01, DL01), and damage from rodent activity (DL01). Daily averaged data sets for all sites are available in the Supplementary Materials.

Total precipitation during our instrument deployment was similar to or greater than historical MAP, whereas average air temperatures reflected historical MAAT. The total precipitation for August 2013- August 2014 for CAN01, CAN02, and DL01 was between 260 (Mendoza Airport) and $280 \mathrm{~mm}$ (Mendoza Observatory), exceeding MAP (220 mm) by 20\%. 
285 The total precipitation for August 2013- August 2014 recorded by our Nacuñan rain gauge was $286 \sim 430 \mathrm{~mm}$, exceeding MAP (326 mm) by $\sim 30 \%$. The total precipitation for August 2014- May

2872015 was $\sim 160 \mathrm{~mm}$ for Mendoza and $280 \mathrm{~mm}$ for Nacuñan, falling below the historical average 288 for each site by at least $10 \%$. Average air temperatures at Mendoza and Nacuñan reflected the 289 historical MAAT's of $17^{\circ} \mathrm{C}$ and $16^{\circ} \mathrm{C}$, respectively, with daily averaged air temperatures of 0-35 $290{ }^{\circ} \mathrm{C}$. Solar radiation for Nacuñan ranged from 0-1275 W/m ${ }^{2}$, with maximum insolation occurring 291 between December and March of each year.

292 Soil temperatures were comparable for all 4 instrumented pits and similar to those of the 293 two nearest sites (1.1 and $1.6 \mathrm{~km}$ ) of Peters et al. (2013) (Figure 3). Average daily soil 294 temperatures ranged from $0-40{ }^{\circ} \mathrm{C}(10 \mathrm{~cm}$ depth $)$ and from $8-35^{\circ} \mathrm{C}(50$ and $100 \mathrm{~cm} \mathrm{depth})$ for 295 all 4 sites. Peters et al. (2013) sensor data from 2010 reported soil temperatures of 0- $33{ }^{\circ} \mathrm{C}$, air 296 temperatures similar to historical MAAT recorded by nearby weather stations $\left(\mathrm{Guido}, 15^{\circ} \mathrm{C}\right.$;

297 Cachueta, $13{ }^{\circ} \mathrm{C}$ ), and precipitation $\sim 30 \%$ below MAP. 

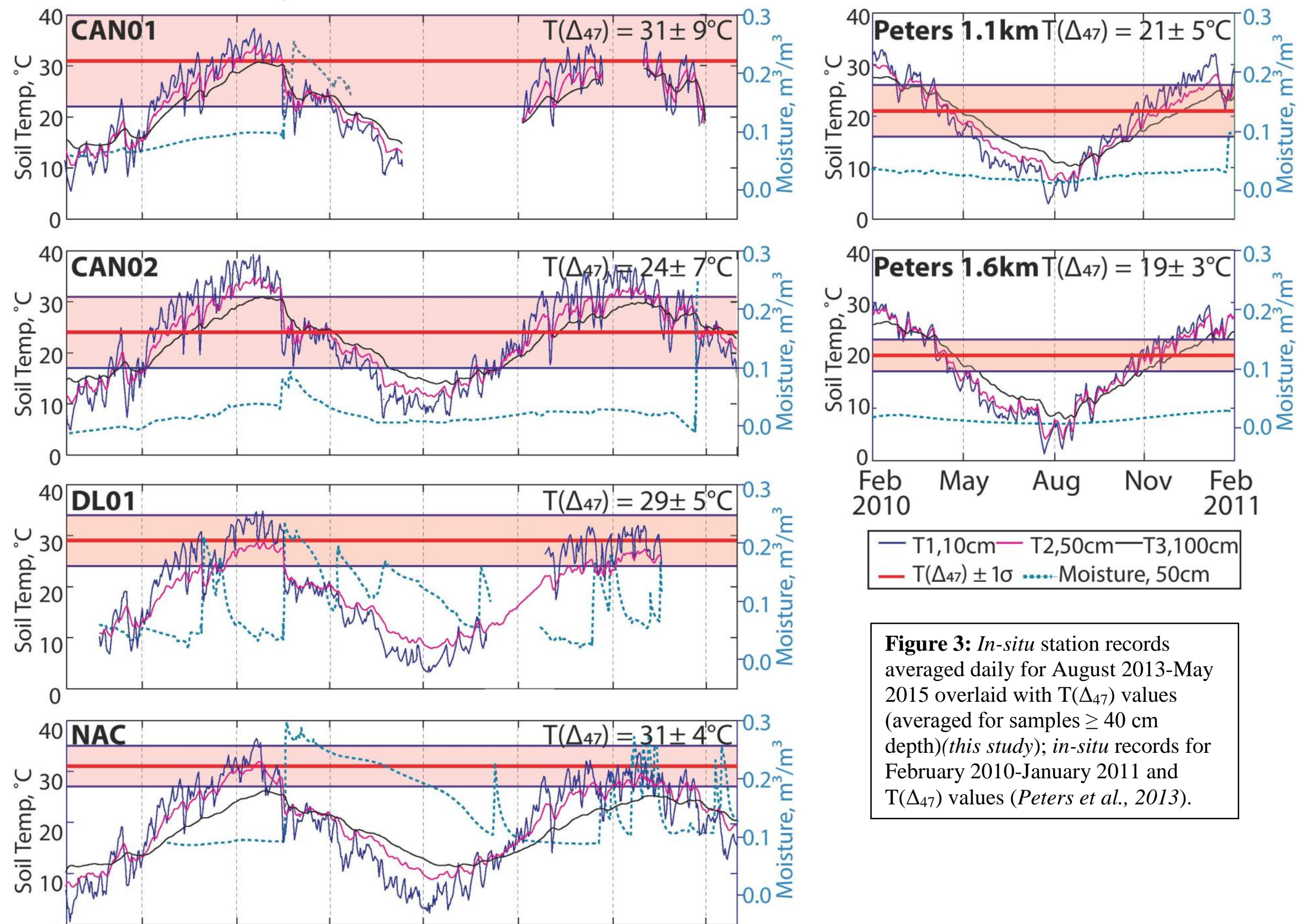

Figure 3: In-situ station records averaged daily for August 2013-May 2015 overlaid with $T\left(\Delta_{47}\right)$ values (averaged for samples $\geq 40 \mathrm{~cm}$ depth)(this study); in-situ records for February 2010-January 2011 and $\mathrm{T}\left(\Delta_{47}\right)$ values (Peters et al., 2013).

Pug Oct Jan Apr Jul Oct Jan
2013


We recorded soil wetting and drying events at each instrumented site, observing soil 300 moistures between 0.00 and $0.30 \mathrm{~m}^{3} / \mathrm{m}^{3}$. According to the sensor manufacturer (Onset), soil

301 302 303 304 305 306 307 308 309 317 April 2015. moistures of $0.30-0.50 \mathrm{~m}^{3} / \mathrm{m}^{3}$ represent wet to saturated soils and values $<0.10 \mathrm{~m}^{3} / \mathrm{m}^{3}$ reflect "oven dry" to "dry" soils. A significant wetting event was captured at $50 \mathrm{~cm}$ depth for all sites in late February 2014, although conditions at CAN02 during this event remained "dry" (peak soil

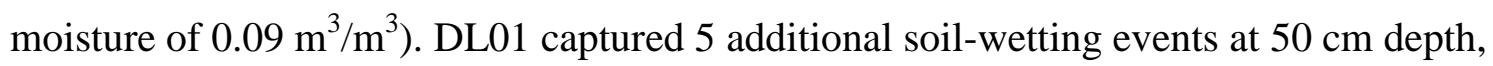
occurring in December 2013, April 2014, and December 2014. Sensors at Nacuñan captured 1 wetting event at $100 \mathrm{~cm}$ depth in late February 2014 and a series of wetting events at $50 \mathrm{~cm}$ depth in December 2014- April 2015. Soils at all 4 sites typically required less than one month to dry to background moisture conditions after wetting events at $50 \mathrm{~cm}$ depth, with the exception of the February 2014 rainstorm, which required 2 (CAN01/CAN02/DL01) to 6 (Nacuñan) months to dry to background conditions.

Soil gas $\mathrm{CO}_{2}$ rose in response to rainfall during the growing season. Nacuñan soil gas $\mathrm{CO}_{2}$ recorded at $50 \mathrm{~cm}$ depth ranged between 0.12 and $0.60 \%$ from February 2014- May 2015, with maximum $\mathrm{CO}_{2}$ occurring in late February- April 2014. $\mathrm{CO}_{2}$ concentrations rose sharply in the middle of the growing season after the late February 2014 rainstorm (>170 mm over 3 days resulting in infiltration to $1 \mathrm{~m}$ depth (Figure 5)). Soil $\mathrm{CO}_{2}$ fell to background levels by late May 2014 and remained low through May 2015, with slight responses to rainfall in summer February-

\subsection{Isotopic results}

Isotopic results are summarized in Table 3 and Figure 4 (see Supplementary Materials for a full summary of replicate analyses). Soil carbonate $\delta^{13} \mathrm{C}$ (range: -6.0 to $-0.3 \%$ (VPDB)) and 
$322 \delta^{18} \mathrm{O}$ (range: -8.0 to $2.3 \%$ (VPDB)) generally decrease with depth. Below $50 \mathrm{~cm}, \delta^{13} \mathrm{C}$ and $\delta^{18} \mathrm{O}$ 323 range from -6.0 to $-2.1 \%$ and -8.5 to $-0.1 \%$, respectively. $\delta^{18} \mathrm{O}_{\mathrm{Sw}}$ values (range: -4.9 to $4.9 \%$ 324 (VSMOW)) were calculated from carbonate $\delta^{18} \mathrm{O}$ and $\mathrm{T}\left(\Delta_{47}\right)$ following Kim and O'Neil (1997) 325 and generally decrease with depth for all pits (Table 3). Below $50 \mathrm{~cm}$ depth, $\delta^{18} \mathrm{O}_{\mathrm{Sw}}$ values for 326 CAN01, CAN02, and DL01 are similar (range: 0.3 to $2.6 \%$ ), while values for Nacuñan are more 327 negative (range: -4.9 to $-3.5 \%$ ).

Sample $\Delta_{47}$ values range from 0.572 to $0.639 \%$, corresponding to $T\left(\Delta_{47}\right)$ values of 43 to

$32920{ }^{\circ} \mathrm{C}$, respectively, using the Kluge et al. (2015) calibration; $\mathrm{T}\left(\Delta_{47}\right)$ values using the Zaarur et 330 al. (2013) calibration lie within 1 standard error of these values (range: 37 to $21^{\circ} \mathrm{C}$ ). Sample 331 replicate analyses (reported in the ARF following Kluge et al. (2015)) of aliquots of the same 332 powders analyzed by Peters et al. (2013) at Caltech (pre-ARF, following Ghosh et al. (2006)) 333 differ by $<2{ }^{\circ} \mathrm{C}$. $\mathrm{T}\left(\Delta_{47}\right)$ values for our study and for Peters et al. (2013) are plotted in Figure 4. Average $T\left(\Delta_{47}\right)$ values are similar for nearby piedmont sites and do not vary 335 systematically with depth. The mean piedmont $\mathrm{T}\left(\Delta_{47}\right)$ is $30 \pm 6{ }^{\circ} \mathrm{C}( \pm 1 \mathrm{SE})$ and Nacuñan $\mathrm{T}\left(\Delta_{47}\right)$ 336 is $29 \pm 4{ }^{\circ} \mathrm{C}$; average $\mathrm{T}\left(\Delta_{47}\right)$ values for samples $\geq 40 \mathrm{~cm}$ depth were $28 \pm 6{ }^{\circ} \mathrm{C}$ and $31 \pm 4{ }^{\circ} \mathrm{C}$, 337 respectively. Comparing individual sites, $\mathrm{T}\left(\Delta_{47}\right)$ for CAN01 and CAN02 samples $\geq 40 \mathrm{~cm}$ depth $338\left(31 \pm 8{ }^{\circ} \mathrm{C}\right.$ and $25 \pm 7^{\circ} \mathrm{C}$, respectively) are statistically different $(\mathrm{T}=3.13, \mathrm{P}<0.05)$, though no 339 other pairings between the four sites produced statistically different $\mathrm{T}\left(\Delta_{47}\right)$ values. A one-way 340 ANOVA test indicated that there were no statistical differences between the four groups using a 341 significance threshold of 0.05 (95\%; see Supplementary Materials). The $\mathrm{T}\left(\Delta_{47}\right)$ of the single 342 sample at the fifth site $\left(30 \pm 4^{\circ} \mathrm{C}, 50 \mathrm{~cm}\right.$ depth $)$ did not differ from the mean values of the other 343 sites. 
345 temperatures (Figure 3). For CAN01, DL01, and Nacuñan, T( $\left.\Delta_{47}\right)$ values are similar to soil

346 temperatures only during the hottest summer months, while CAN02 values reflect late spring and

347 late summer soil temperatures. T $\left(\Delta_{47}\right)$ values exceed MAAT and MAST and equal or exceed the

348 average hottest monthly mean soil temperature (HMST) at $50 \mathrm{~cm}$, with the exception of CAN02,

349 which falls between MAST and HMST (Figure 4). The T( $\left.\Delta_{47}\right)$ values of Peters et al. (2013) (1.1

$350 \mathrm{~km}$ and $1.6 \mathrm{~km}$ sites) more closely approach local MAST and are similar to soil temperatures in

351 late spring, early fall, and for a brief period during summer (January 2011); these values exceed

352 MAAT and fall between MAST and HMST. 
Table 3: Summary of carbonate sample isotopic analyses

\begin{tabular}{|c|c|c|c|c|c|c|c|c|}
\hline \multirow[t]{2}{*}{ Sample: } & \multirow[t]{2}{*}{$n$} & \multirow[t]{2}{*}{$\begin{array}{r}\delta^{13} \mathrm{C}^{\mathrm{a}}(\%) \\
(\mathrm{VPDB})\end{array}$} & \multirow[t]{2}{*}{$\begin{array}{r}\delta^{18} \mathrm{O}^{\mathrm{a}}(\% o) \\
(\mathrm{VPDB})\end{array}$} & \multirow{2}{*}{$\begin{array}{r}\Delta_{47} \pm 1 \mathrm{SE}^{\mathrm{a}}(\%) \\
\text { Calibration: }\end{array}$} & \multicolumn{2}{|c|}{$\mathrm{T}\left(\Delta_{47}\right) \pm 1 \mathrm{SE}\left({ }^{\circ} \mathrm{C}\right)$} & \multicolumn{2}{|c|}{$\begin{array}{c}\text { Soil water } \delta^{18} \mathrm{O}^{\mathrm{b}}(\% \mathbf{0}) \\
\text { (VSMOW) }\end{array}$} \\
\hline & & & & & $\begin{array}{r}\text { Kluge et al., } \\
2015 \\
\end{array}$ & $\begin{array}{r}\text { Zaarur et } \\
\text { al., } 2013\end{array}$ & $\begin{array}{r}\text { Kluge et al., } \\
2015 \\
\end{array}$ & $\begin{array}{r}\text { Zaarur et } \\
\text { al., } 2013 \\
\end{array}$ \\
\hline \multicolumn{9}{|c|}{ CAN01, 1.0km elevation } \\
\hline $10 \mathrm{~cm}$ & 3 & -1.8 & -3.7 & $0.572 \pm 0.011^{\mathrm{c}}$ & $43 \pm 4$ & $37 \pm 3$ & $2.1 \pm 0.9$ & $1.0 \pm 0.6$ \\
\hline $25 \mathrm{~cm}$ & 3 & -0.3 & -2.2 & $0.609 \pm 0.012^{c}$ & $29 \pm 4$ & $28 \pm 3$ & $1.0 \pm 0.9$ & $0.7 \pm 0.7$ \\
\hline $40 \mathrm{~cm}$ & 3 & -1.9 & -3.4 & $0.601 \pm 0.014$ & $32 \pm 5$ & $30 \pm 4$ & $0.4 \pm 1.0$ & $-0.1 \pm 0.7$ \\
\hline $55 \mathrm{~cm}$ & 3 & -3.1 & -3.4 & $0.609 \pm 0.013$ & $30 \pm 5$ & $28 \pm 3$ & $-0.1 \pm 0.9$ & $-0.5 \pm 0.6$ \\
\hline $70 \mathrm{~cm}$ & 2 & -3.5 & -1.9 & $0.595 \pm 0.018$ & $35 \pm 7$ & $31 \pm 5$ & $2.4 \pm 1.3$ & $1.8 \pm 1.0$ \\
\hline $100 \mathrm{~cm}$ & 2 & -2.6 & -3.2 & $0.612 \pm 0.045$ & $29 \pm 17$ & $27 \pm 11$ & $-0.1 \pm 4.6$ & $-0.4 \pm 3.5$ \\
\hline Avg. $\geq 40 \mathrm{~cm} \mathrm{dep}$ & & -2.8 & -3.0 & $0.604 \pm 0.023$ & $31 \pm 8$ & $29 \pm 6$ & $1.0 \pm 2.0$ & $0.2 \pm 1.5$ \\
\hline \multicolumn{9}{|c|}{ CANO2, $1.0 \mathrm{~km}$ elevation } \\
\hline $10 \mathrm{~cm}$ & $3^{\mathrm{d}}$ & -0.9 & 0.9 & $0.610 \pm 0.011^{\mathrm{c}}$ & $29 \pm 4$ & $28 \pm 3$ & $4.2 \pm 0.7$ & $3.9 \pm 0.5$ \\
\hline $25 \mathrm{~cm}$ & $3^{d}$ & -3.1 & 2.3 & $0.627 \pm 0.011$ & $24 \pm 4$ & $23 \pm 3$ & $4.4 \pm 0.7$ & $4.4 \pm 0.5$ \\
\hline $40 \mathrm{~cm}$ & $2^{\mathrm{d}}$ & -3.7 & 0.8 & $0.615 \pm 0.013^{c}$ & $28 \pm 5$ & $26 \pm 3$ & $3.7 \pm 0.9$ & $3.5 \pm 0.6$ \\
\hline $55 \mathrm{~cm}$ & $2^{d}$ & -4.7 & -0.1 & $0.617 \pm 0.027$ & $27 \pm 9$ & $26 \pm 6$ & $2.6 \pm 1.8$ & $2.4 \pm 1.2$ \\
\hline $70 \mathrm{~cm}$ & & -2.1 & -0.8 & $0.625 \pm 0.017$ & $24 \pm 6$ & $24 \pm 4$ & $1.4 \pm 1.1$ & $1.4 \pm 0.8$ \\
\hline $85 \mathrm{~cm}$ & $3^{\mathrm{d}}$ & -3.9 & -1.9 & $0.639 \pm 0.015$ & $20 \pm 5$ & $21 \pm 3$ & $-0.6 \pm 1.0$ & $-0.4 \pm 0.7$ \\
\hline $100 \mathrm{~cm}$ & $2^{\mathrm{d}}$ & -5.0 & -1.8 & $0.615 \pm 0.027$ & $28 \pm 10$ & $26 \pm 7$ & $1.1 \pm 1.9$ & $0.9 \pm 1.3$ \\
\hline Avg. $\geq 40 \mathrm{~cm} \mathrm{dep}$ & & -3.9 & -0.8 & $0.627 \pm 0.020$ & $25 \pm 7$ & $25 \pm 5$ & $1.7 \pm 1.3$ & $1.5 \pm 0.9$ \\
\hline \multicolumn{9}{|c|}{ CAN03, 1.0km elevation } \\
\hline $50 \mathrm{~cm}$ & 3 & -4.7 & -2.9 & $0.609 \pm 0.011^{\mathrm{c}}$ & $30 \pm 4$ & $28 \pm 3$ & $0.4 \pm 0.8$ & $0.0 \pm 0.6$ \\
\hline \multicolumn{9}{|c|}{ DL01, 1.0km elevation } \\
\hline $20 \mathrm{~cm}$ & 3 & -1.2 & -1.0 & $0.584 \pm 0.011^{\mathrm{c}}$ & $39 \pm 4$ & $34 \pm 3$ & $4.0 \pm 0.8$ & $3.2 \pm 0.5$ \\
\hline $40 \mathrm{~cm}$ & 4 & -4.1 & -1.4 & $0.630 \pm 0.019$ & $23 \pm 6$ & $23 \pm 5$ & $0.5 \pm 1.3$ & $0.6 \pm 0.9$ \\
\hline $70 \mathrm{~cm}$ & 2 & -5.2 & -2.5 & $0.616 \pm 0.013^{\mathrm{c}}$ & $27 \pm 5$ & $26 \pm 3$ & $0.3 \pm 0.9$ & $0.0 \pm 0.7$ \\
\hline $100 \mathrm{~cm}$ & 2 & -5.2 & -3.0 & $0.590 \pm 0.013^{c}$ & $36 \pm 5$ & $32 \pm 3$ & $1.6 \pm 1.4$ & $1.9 \pm 1.1$ \\
\hline Avg. $\geq 40 \mathrm{~cm} \mathrm{dep}$ & & -4.8 & -2.3 & $0.612 \pm 0.015$ & $29 \pm 5$ & $27 \pm 4$ & $0.8 \pm 1.2$ & $0.5 \pm 0.8$ \\
\hline \multicolumn{9}{|c|}{ Nacuñan, 0.6km elevation *(carbonate nodule samples) } \\
\hline $20 \mathrm{~cm}$ & 3 & -5.5 & -6.7 & $0.634 \pm 0.012$ & $21 \pm 4$ & $22 \pm 3$ & $-5.1 \pm 0.9$ & $-5.0 \pm 0.7$ \\
\hline $50 \mathrm{~cm}$ & $4^{\mathrm{d}}$ & -6.0 & -8.3 & $0.585 \pm 0.011$ & $38 \pm 4$ & $34 \pm 3$ & $-3.4 \pm 0.8$ & $-4.2 \pm 0.6$ \\
\hline $85 \mathrm{~cm}$ & $3^{\mathrm{d}}$ & -5.7 & -7.6 & $0.622 \pm 0.011^{\mathrm{c}}$ & $25 \pm 4$ & $25 \pm 3$ & $-5.2 \pm 0.7$ & $-5.3 \pm 0.5$ \\
\hline $100 \mathrm{~cm}$ & 2 & -5.5 & -8.5 & $0.605 \pm 0.013^{c}$ & $31 \pm 5$ & $29 \pm 3$ & $-5.0 \pm 1.2$ & $-5.4 \pm 0.9$ \\
\hline Avg. $\geq 40 \mathrm{~cm} \mathrm{dep}$ & & -5.7 & -8.1 & $0.604 \pm 0.012$ & $31 \pm 4$ & $29 \pm 3$ & $-4.5 \pm 0.9$ & $-5.0 \pm 0.7$ \\
\hline \multicolumn{9}{|c|}{ Peters et al. $2013,1.1 \mathrm{~km}$ elevation } \\
\hline $50 \mathrm{~cm}, 2013$ & & -5.9 & -1.2 & $0.686 \pm 0.019$ & Pre-ARF: & $17 \pm 4$ & Pre-ARF: & $-0.5 \pm 0.9$ \\
\hline $50 \mathrm{~cm}, 2015$ & & -5.9 & -1.7 & $0.645 \pm 0.019$ & ARF, Kluge: & $18 \pm 4$ & ARF, Kluge: & $-0.8 \pm 0.9$ \\
\hline Pit average: & & $-5.1^{e}$ & $-2.7^{e}$ & $0.671 \pm 0.023^{c}$ & Pre-ARF: & $20 \pm 4$ & Pre-ARF: & $-1.4 \pm 0.7$ \\
\hline \multicolumn{9}{|c|}{ Peters et al. $2013,1.6 \mathrm{~km}$ elevation } \\
\hline $50 \mathrm{~cm}, 2013$ & & -5.5 & -9.7 & $0.688 \pm 0.019$ & Pre-ARF: & $16 \pm 3$ & Pre-ARF: & $-9.2 \pm 0.6$ \\
\hline $50 \mathrm{~cm}, 2015$ & & -5.9 & -9.6 & $0.663 \pm 0.019$ & ARF, Kluge: & $13 \pm 3$ & ARF, Kluge: & $-9.9 \pm 0.7$ \\
\hline Pit average: & & $-6.0^{e}$ & $-10.5^{e}$ & $0.675 \pm 0.013^{e}$ & Pre-ARF: & $19 \pm 3$ & Pre-ARF: & $-9.4 \pm 0.6$ \\
\hline
\end{tabular}

$354{ }^{\mathrm{a}}$ Carbonate $\delta^{13} \mathrm{C}, \delta^{18} \mathrm{O}$, reported as mean and $\Delta_{47}$ reported as weighted mean of replicates $(n)$ for each individual sample.

355 Average external error (1SE) for replicates of a sample is $\pm 0.03 \%$ for $\delta^{13} \mathrm{C}$ and for $\delta^{18} \mathrm{O}$, and $\pm 0.019 \%$ for $\Delta_{47}$.

$356{ }^{\mathrm{b}}$ Soil water $\delta^{18} \mathrm{O}$ was calculated using the calcite-water O-isotope fractionation equation of Kim and O'Neil (1997).

357 Uncertainty in soil water $\delta^{18} \mathrm{O}$ was calculated by propagating errors in $\mathrm{T}\left(\Delta_{47}\right)$.

$358{ }^{c}$ For samples with low SE for replicates, SE was assigned using the long-term SD of a standard run during the same

359 period of time divided by $\operatorname{sqrt}(n)$, where $n$ is the number of sample replicates, following Peters et al. (2013) and

360 Huntington et al. (2009).

$361{ }^{\mathrm{d}}$ Samples noted with $n^{\mathrm{d}}$ were analyzed using an additional two replicates for $\delta^{13} \mathrm{C}$ and $\delta^{18} \mathrm{O}$ measurements using a Kiel

362 III Carbonate Device coupled to a dual-inlet Thermo Finnigan Delta Plus IRMS at the University of Washington Isolab.

$363{ }^{\mathrm{e}}$ Peters et al., (2013) (pre-ARF) average external error (1SE) for replicates is $\pm 0.04 \%$ o for $\delta^{13} \mathrm{C}, \pm 0.002 \%$ o for $\delta^{18} \mathrm{O}$, and

$364 \pm 0.016 \%$ or $\Delta_{47}$. 

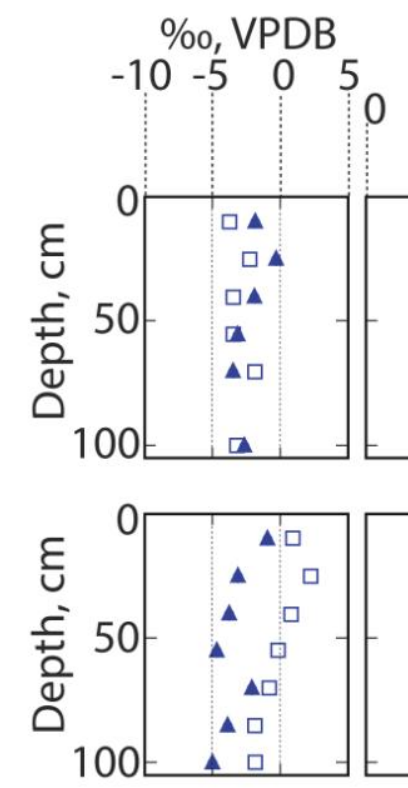

CAN02, 1.0km
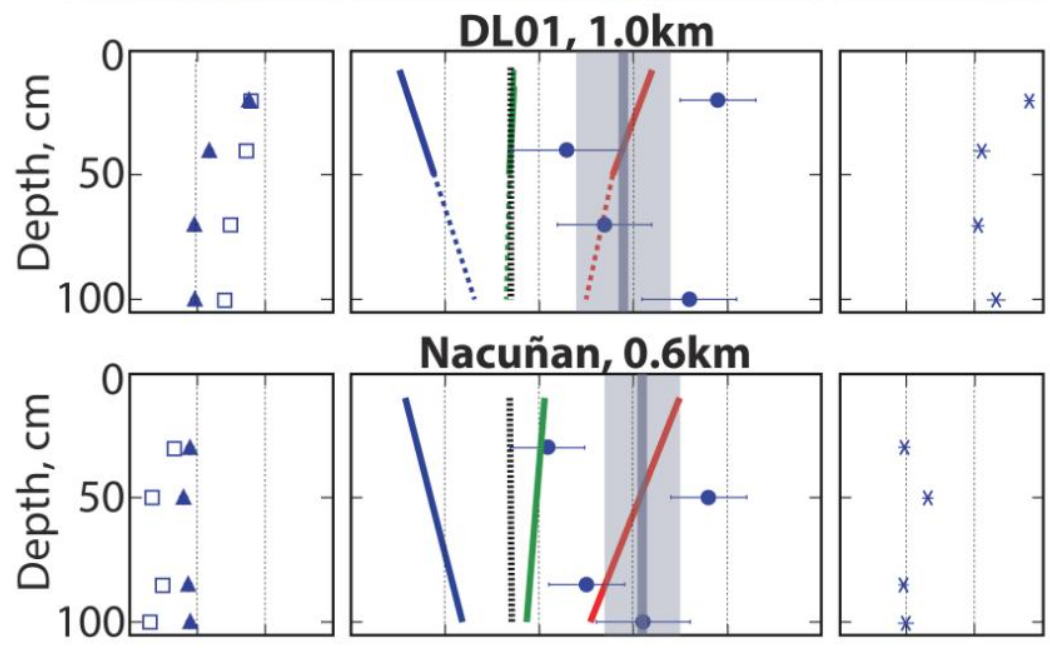

Nacuñan, 0.6km
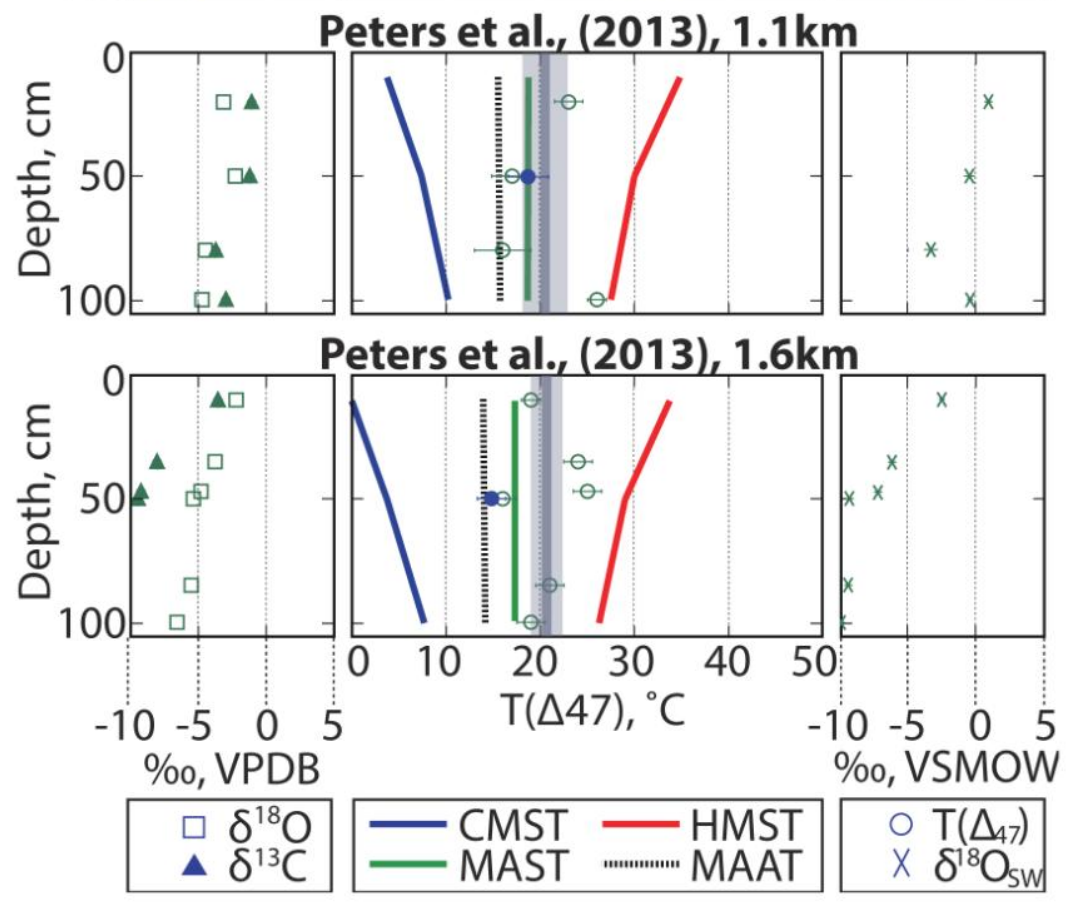

Figure 4: Soil carbonate isotope data from this study (blue symbols) and from Peters et al. (2013, green symbols).

Left panels: carbonate $\delta^{13} \mathrm{C}$ (VPDB, triangles) and $\delta^{18} \mathrm{O}$ (VPDB, squares) values.

Middle panels: soil carbonate $\mathrm{T}\left(\Delta_{47}\right) \pm 1 \mathrm{SE}$ calculated using equation 5 of Kluge et al. (2015)

(blue circles: this study; green circles: Peters et al. 2013). Gray vertical bars and shaded boxes indicate the mean and standard deviation across $\mathrm{T}\left(\Delta_{47}\right)$ for samples $\geq 40 \mathrm{~cm}$ depth in a soil profile. Lines represent coldest mean soil temperature (CMST, blue), mean annual soil temperature (MAST, green), hottest mean soil temperature (HMST, red), and mean annual air temperature (MAAT, black), extrapolated from 1.5 years of soil temperatures recorded at 10 , 50 , and $100 \mathrm{~cm} \mathrm{depth,} \mathrm{and} \mathrm{from} \mathrm{air}$ temperatures recorded at Mendoza Airport (CAN01, CAN02, DL01) and by instrumentation at Nacuñan.

Right panels: calculated $\delta^{18} \mathrm{O}_{\mathrm{SW}}$ (VSMOW, crosses). 


\section{Discussion}

\subsection{Radiocarbon ages and $C$ and $O$ isotope trends}

Radiocarbon analyses for carbonate coatings at DL01 and nodules at Nacuñan produced ages $\leq 16 \mathrm{ky}$, consistent with the early stage (Gile et al., 1966) and small nodule size (Retallack, 2005) of Holocene/ Late Pleistocene pedogenic carbonates. ${ }^{14} \mathrm{C}$ is incorporated into coatings or nodules as soil carbonates grow over time, resulting in time-averaged radiocarbon ages that are 404 typically interpreted as underestimates of the true age of carbonate formation (Amundson et al. 1994; Yang et al. 1994). However, the difference between true age and radiocarbon age is likely greater at the surface than at depth because near-surface soil carbonate may more easily be

407 contaminated with younger ${ }^{14} \mathrm{C}$. Indeed, at Nacuñan ages increase systematically with depth from $408 \sim 6$ to $16 \mathrm{ky} \mathrm{BP,} \mathrm{matching} \mathrm{theoretical} \mathrm{predictions} \mathrm{(Yang} \mathrm{et} \mathrm{al.} \mathrm{1994).} \mathrm{The} \mathrm{frequency} \mathrm{of} \mathrm{carbonate-}$ 409 forming events may also impact radiocarbon ages: if carbonates form more frequently at the 410 surface than at depth due to frequent shallow soil wetting events, the incorporation of additional, 411 younger ${ }^{14} \mathrm{C}$ may produce more recent radiocarbon ages nearer the surface. Overall, radiocarbon 412 analyses for nodules at Nacuñan suggest Holocene/ Late Pleistocene formation in relatively 413 stable soil.

414 Carbonate $\delta^{13} \mathrm{C}$ and $\delta^{18} \mathrm{O}$ values generally increase towards the surface, indicating 415 undisturbed soil profiles with near-surface soil water evaporation and soil gas exchange with 416 atmospheric $\mathrm{CO}_{2}$ (Cerling and Quade, 1993). Below $50 \mathrm{~cm}$ depth, the range of $\delta^{13} \mathrm{C}$ values 417 reflects mixed $\mathrm{C}_{4} / \mathrm{C}_{3}$ environments with lower soil productivity at CAN01 and CAN02 (-5.0 418 to $-2.1 \%$ ) than at DL01 and Nacuñan (-6.0 to $-5.2 \%$ ), which is supported by our vegetation 419 coverage survey (Table 2; Cerling, 1988). 

averaged over depth for our soil profiles are not significantly different. This suggests that nearby

424 sites in a single precipitation regime at a single elevation will be indistinguishable in $\mathrm{T}\left(\Delta_{47}\right)$ even 425 under varying $\mathrm{C}_{4} / \mathrm{C}_{3}$ distributions within the $4-6{ }^{\circ} \mathrm{C}$ resolution ( $\mathrm{n}=3$ replicates) of the clumped 426 isotope method. This challenges the expectation that soil carbonate formation temperatures will 427 be higher under $C_{4}$ than under $C_{3}$ plant growth (e.g. Breecker et al. 2009; Meyer et al. 2014), and 428 agrees with phenological and ecophysiological studies that show $\mathrm{C}_{3}$ plant activity during wet 429 pulses, in spite of warm temperatures (Meglioli et al., 2015; Villagra et al., 2011; Giordano et al., 430 2011). Additionally, no difference was found between sites with carbonate undercoatings 431 (piedmont sites) and nodules (Nacuñan). However, while $\mathrm{T}\left(\Delta_{47}\right)$ values are indistinguishable among our sites, our values exceed 433 those of the nearest two sites studied by Peters et al. (2013) by $\sim 10{ }^{\circ} \mathrm{C}$, despite comparable 434 surface and in-situ temperature conditions. Peters et al. (2013) suggested that the average $\sim 20{ }^{\circ} \mathrm{C}$ $435 \mathrm{~T}\left(\Delta_{47}\right)$ value for their sites was due to the summer-focused rainfall in this region, which could 436 result in soil drying and carbonate formation during late fall when soils are closer to MAST than 437 HMST. According to our sensor data, while soils may be wet from mid-summer through fall, 438 carbonate formation in response to the early stage of soil drying or between discrete summer rain 439 events could significantly impact $\mathrm{T}\left(\Delta_{47}\right)$, resulting in hot summer values. The $\sim 10{ }^{\circ} \mathrm{C}$ difference 440 between these two studies suggests that there is a potential for substantial spatial variability in $441 \mathrm{~T}\left(\Delta_{47}\right)$ at the same elevation in a region dominated by the same precipitation and vegetation 442 regime. The nearest Peters site $(1.1 \mathrm{~km})$ differs from DL01 by only $100 \mathrm{~m}$ elevation and $20 \mathrm{~km}$ 443 distance; it may be possible that local hydrology, topographic features, or differences in soil 
444 water chemistry may contribute to a difference in the timing and temperature of carbonate

445 formation. In particular, the Peters $1.1 \mathrm{~km}$ site lies $<0.5 \mathrm{~km}$ from the Mendoza River, which

446 transports limestone rich sediment from the high Andes and causes periodic flooding that could

447 alter soil moisture and chemistry in this site. Flooding and subsequent soil drying in winter,

448 spring, or fall could have contributed to decreased $\mathrm{T}\left(\Delta_{47}\right)$ values, although further investigation

449 into the age, frequency of flooding, and sub-surface physical and chemical characteristics of

450 these sites would be necessary to say more about potential impacts on carbonate formation. The

451 location of the Peters $1.6 \mathrm{~km}$ site in a narrow, N-S portion of the Río Mendoza valley may also

452 influence local productivity and soil hydrology, which could contribute to the difference in

$453 \mathrm{~T}\left(\Delta_{47}\right)$ values between these studies.

$454 \quad 5.3$ Invariance of $T\left(\Delta_{47}\right)$ with depth

$455 \mathrm{~T}\left(\Delta_{47}\right)$ values from each sampled pit did not vary systematically or decrease towards

456 MAST with depth (Figure 4), consistent with data from other studies (Quade et al., 2013; Peters

457 et al., 2013). The simplest explanation for this invariance would be carbonate formation during

458 spring or fall when the soil profile is near isothermal, such that the range of $\mathrm{T}\left(\Delta_{47}\right)$ values would

459 be constrained through the soil profile. Our instrumental records show that the conditions for a

460 seasonally isothermal soil occur over a narrow range of time (1-2 weeks) during the spring and

461 fall in which soil temperatures are near MAAT. However, our observed $\mathrm{T}\left(\Delta_{47}\right)$ values range from

462 24- $31{ }^{\circ} \mathrm{C}$, at least 6- $10{ }^{\circ} \mathrm{C}$ higher than MAAT, spring, or fall soil temperatures at any

463 instrumented pit. This discrepancy is more than can be explained by temperature fluctuations that

464 may have occurred over the hundreds to thousands of years required for soil carbonate formation

465 processes to occur in these sites, suggesting that some other process must account for the

466 observed temperature invariance with depth. 


\subsection{Isothermal conditions after rainfall events}

Generally, in-situ soil temperatures recorded at all four sites immediately following

470 significant soil wetting events are similar to carbonate formation $T\left(\Delta_{47}\right)$ values and reflect the

471 isothermal conditions seen in our $\mathrm{T}\left(\Delta_{47}\right)$ profiles. High frequency variations in near-surface

472 temperature and moisture may explain some of the scatter in $T\left(\Delta_{47}\right)$ values with depth. However,

473 since $T\left(\Delta_{47}\right)$ is generally consistent with depth, averaging values throughout a soil profile should

474 provide a robust measure of average soil temperatures following rainfall events. Soil moisture

475 sensors at all sites captured soil wetting at $50 \mathrm{~cm}$ depth after a large late February 2014

476 rainstorm, immediately after which near-isothermal conditions were registered at 10, 50, and 100

$477 \mathrm{~cm}$ (Figure 3). In the first 1-3 days following this event, soil temperatures at CAN01 converged

478 at $\sim 30{ }^{\circ} \mathrm{C}$, within the range of uncertainty of $\mathrm{T}\left(\Delta_{47}\right)$ for this site (Figure 3 ). During the months

479 after this event when the soil was drying back to baseline conditions, soil temperatures fell well

480 below the range of $\mathrm{T}\left(\Delta_{47}\right)$ values for this site, such that carbonate formation later in the drying

481 curve would result in lower $\mathrm{T}\left(\Delta_{47}\right)$ values than we observed at all depths. This infiltration-driven

482 cooling of soil temperatures to isothermal $\mathrm{T}\left(\Delta_{47}\right)$ values in the early part of the soil drying curve

483 is seen after large precipitation events at all sites. If carbonate were to form at these times at any

484 depth in the soil, it would contribute to a warm-season biased, isothermal $\mathrm{T}\left(\Delta_{47}\right)$ depth profile,

485 such as we see in Figure 4.

486 If isothermal profiles are not caused by carbonate formation while the soil profile is

487 isothermal, the timing and depth of infiltration may govern formation temperatures at different

488 depths in such a way that hot isothermal $\mathrm{T}\left(\Delta_{47}\right)$ 's are reached. At Nacuñan, more than $50 \%$ of

489 wetting events recorded at $10 \mathrm{~cm}$ depth did not reach the $50 \mathrm{~cm}$ soil moisture sensor, and $90 \%$ of 
wetting events recorded at $50 \mathrm{~cm}$ depth did not reach the $100 \mathrm{~cm}$ soil moisture sensor. Brief

491 periods of soil drying after small rainstorms with shallow infiltration could result in more

492 frequent carbonate formation near the surface than at depth. These small events occur at

493 Nacuñan throughout the spring, summer, and fall. While spring and fall events could contribute

494 to cooler carbonate formation temperatures, the bulk of precipitation in this region occurs in

495 summer and frequent wetting and drying events during the hottest months could bias $\mathrm{T}\left(\Delta_{47}\right)$

496 values to seasonal summer soil temperatures. Below $50 \mathrm{~cm}$ depth, soil wetting and drying appear

497 to be caused only by large, infrequent mid-summer rainstorms. Hot $\mathrm{T}\left(\Delta_{47}\right)$ values at depth could

498 represent soil carbonate formation during the early part of soil drying immediately after these

499 individual wetting events.

$500 \quad$ Our findings are consistent with a recent study of soil carbonates from Wyoming and

501 Nebraska by Hough et al. (2014), who used air temperature and soil carbonate $\mathrm{T}\left(\Delta_{47}\right)$ data from a

502 single depth per site to propose that soil carbonate forms during soil drying in early summer and

503 after mid-late summer precipitation. By providing soil temperature, soil moisture, and $\mathrm{T}\left(\Delta_{47}\right)$

504 data with depth, we build on this work to suggest that high temperatures and isothermal

505 conditions recorded in $\Delta_{47}$ signals are accounted for by carbonate formation occurring

506 immediately after precipitation events, and not during the progressive drying out of the soil at the

507 tail end of the wet season, as suggested by Breecker et al. (2009) and Peters et al. (2013), when

508 observed soil temperatures are too low to be reconciled with $\mathrm{T}\left(\Delta_{47}\right)$ values. Furthermore, we

509 suggest that shallow carbonate formation $(\leq 50 \mathrm{~cm}$ depth) occurs in response to more frequent

510 precipitation events than carbonate formation deeper in the soil profile. Carbonate $\mathrm{T}\left(\Delta_{47}\right)$ values

$511 \geq 50 \mathrm{~cm}$ depth may reflect soil conditions just after large, discrete mid-summer rainstorms, while

512 shallow carbonates integrate $\mathrm{T}\left(\Delta_{47}\right)$ values from formation throughout spring, summer, and fall, 
513 with summer soil wetting and drying events dominating the $\Delta_{47}$ signal. Under these conditions,

514 carbonates throughout the soil profile could reflect near-isothermal summer formation

515 temperatures, as observed in Figure 4.

516

$517 \quad 5.5$ Conditions of calcite supersaturation

518 In the context of soil wetting events discussed above, if the soil profile is permanently

519 supersaturated in calcite, it is reasonable to assume that carbonate formation can begin early in

520 the soil drying curve, allowing for the hot, isothermal temperatures occurring immediately after

521 precipitation events at these sites to be recorded in $\mathrm{T}\left(\Delta_{47}\right)$ formation temperature estimates.

522 Permanent calcite supersaturation has been demonstrated in other arid and hyperarid

523 environments (Inskeep and Bloom, 1985; Hamdi-Aissa et al., 2004; Marion et al., 2008). At

524 Nacuñan, significant dust influxes carried by zonda winds from the eastern slope of the Andes

525 contribute to near-saturated $\mathrm{Ca}^{2+}$ concentration in surface soils, which should be relatively

526 constant with depth (Jobbagy and Jackson 2001). As a first-pass estimate for determining the

527 seasonality of $\mathrm{CaCO}_{3}$ supersaturation at Nacuñan, equation 2 was solved using soil temperature

528 and $\mathrm{pCO}_{2}$ data from $50 \mathrm{~cm}$ with the minimum value of $\mathrm{Ca}^{2+}$ concentration reported from surface

529 soils (0-20 cm depth) in previous studies at Nacuñan (1.5-2.0 mmol/L; Rossi and Villagra, 2003;

530 Rossi, 2004). Alphas were calculated for February 2014- May 2015, assuming a constant $\mathrm{Ca}^{2+}$

531 concentration of $1.5 \mathrm{mmol} / \mathrm{L}$ throughout the year. Estimated $\alpha_{\text {calcite }}$ values were always greater

532 than 1, suggesting that persistent conditions of $\mathrm{CaCO}_{3}$ supersaturation should allow for calcite

533 precipitation at any time that water is removed from the soil (Figure 5). The lowest alpha values

534 occurred in early March 2014, coincident with maximum observed soil $\mathrm{pCO}_{2}$, and increasing

535 calcite supersaturation was seen as the soil dried out and plant activity declined in winter. While 
the assumption of constant $\mathrm{Ca}^{2+}$ concentration is a considerable oversimplification during soil wetting and soil dewatering by evaporation and root uptake, $\mathrm{Ca}^{2+}$ concentration must fall significantly below the measured range (20-50\%) under the high soil temperatures and low $\mathrm{pCO}_{2}$ conditions observed in order to allow for significant calcite dissolution. While it appears that Nacuñan experiences permanent calcite supersaturation that would allow for carbonate formation to begin early in the soil drying curve, resulting in the hot, isothermal $\mathrm{T}\left(\Delta_{47}\right)$ values observed at this site, further information on the distribution of soluble chemical species in this location would be necessary to more accurately demonstrate conditions of permanent or seasonal supersaturation and to predict conditions favoring calcite dissolution or precipitation.
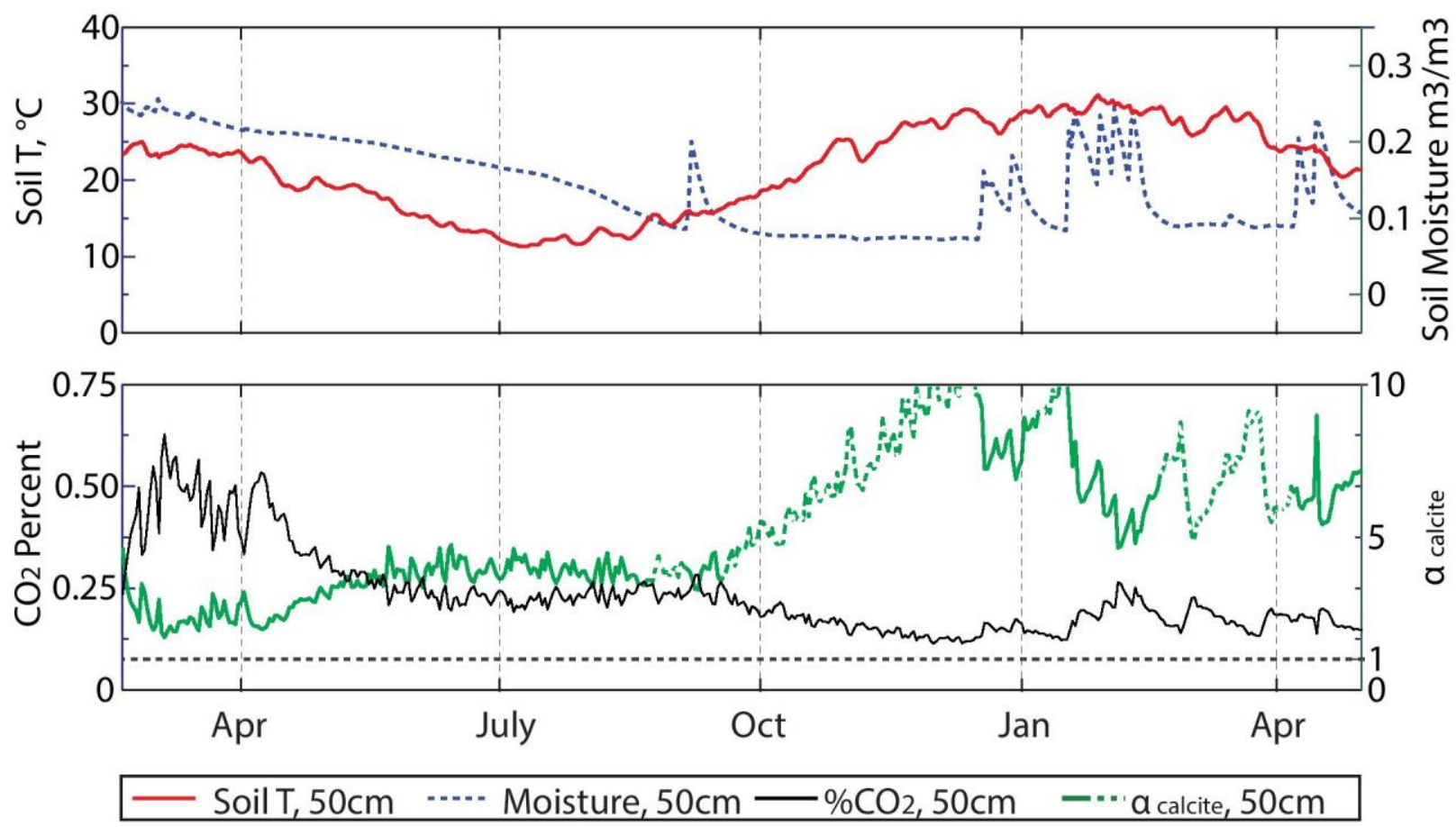

Figure 5: In-situ Nacuñan records (soil temperature, soil moisture, and soil gas $\mathrm{CO}_{2}$ concentration at $50 \mathrm{~cm}$ ) with calculated $\alpha_{\text {calcite }}$ values, mid-February 2014- May 2015, assuming a constant $\mathrm{Ca}^{2+}$ concentration of $1.5 \mathrm{mmol} / \mathrm{L}$. In order for $\alpha_{\text {calcite }}$ to fall $<1$ (favoring calcite dissolution), $\mathrm{Ca}^{2+}$ concentration must be reduced by $20 \%$ (to $1.2 \mathrm{mmol} / \mathrm{L}$ ) in March- May 2014 when $\mathrm{pCO}_{2}$ is highest, by $33 \%$ (to $<1.0 \mathrm{mmol} / \mathrm{L}$ ) in May- September 2014 , and by $50 \%$ (to $<0.75$ $\mathrm{mmol} / \mathrm{L}$ ) after September 2014. Solid portions of the $\alpha_{\text {calcite }}$ line correspond to periods when the soil moisture at $50 \mathrm{~cm}$ is $>0.1 \mathrm{~m}^{3} / \mathrm{m}^{3}$. 
This study results in two key findings that should inform future application of the

556 clumped isotope geothermometer to estimate formation temperatures of pedogenic carbonates.

557 1) For our four arid sites under the same precipitation regime at similar elevations with varying

$558 \quad \mathrm{C}_{4} / \mathrm{C}_{3}$ biomass, site-to-site variability in soil carbonate undercoating or nodule $\mathrm{T}\left(\Delta_{47}\right)$ records

559 is negligible, such that $\mathrm{T}\left(\Delta_{47}\right)$ records need not be adjusted to account for vegetation type.

560 However, there is significant variation between $T\left(\Delta_{47}\right)$ values calculated for this study and for

561 nearby sites in the Río Mendoza valley studied by Peters et al. (2013); we hypothesize that

562 these differences are due to topographic setting and proximity to the Río Mendoza. This

563 suggests the potential for strong local controls on soil hydrology that may result in systematic

564 spatial variations in $\mathrm{T}\left(\Delta_{47}\right)$.

565 2) $\mathrm{T}\left(\Delta_{47}\right)$ values were found to be invariant to $1 \mathrm{~m}$ depth. This suggests that for a summer

566 precipitation regime in a semi-arid region, soil carbonate formation is restricted to intervals

567 when the soil profile is isothermal (occurring during either the transition in seasons or after

568 large soil wetting events), or that a variation in the frequency of soil carbonate formation

569 events at different depths results in hot, isothermal $\mathrm{T}\left(\Delta_{47}\right)$ values. Thus, potential

570 (paleo)precipitation regimes should be carefully considered using soil geochemistry or

571 physical properties (e.g., Retallack, 1994; Retallack, 2005; Royer, 1999; Hyland and Sheldon,

$572 \quad 2013 ; 2015)$ when applying the carbonate clumped isotope geothermometer to

573 paleoenvironmental reconstructions.

574

575 6. Conclusions 
With its summer-only precipitation regime and $\mathrm{C}_{4} / \mathrm{C}_{3}$ transition, the eastern Andean

577 Piedmont is an ideal location for investigating the potential influence of vegetation type and site-

578 specific controls on variability in pedogenic carbonate clumped isotope records. While it appears

579 that climatic conditions and $\mathrm{C}_{4} / \mathrm{C}_{3}$ distributions have varied significantly over the 1000 's of years 580 integrated by soil carbonates relative to our $<2$ years of in-situ soil and atmospheric data, future

581 work should consider whether the impact of these climate changes can be resolved within the 4-6

$582{ }^{\circ} \mathrm{C}$ uncertainty of the clumped isotope record (Gil et al., 2014; Labraga and Villalba, 2008; Silva

583 et al. 2011). We find that carbonate clumped isotope formation temperatures are invariant

584 between sites of $\sim 0.02-0.46 \mathrm{C}_{4} /$ total vegetation biomass by groundcover, fall at or above HMST, 585 and are near-isothermal between 10 and $100 \mathrm{~cm}$ depth. We suggest that isothermal $\mathrm{T}\left(\Delta_{47}\right)$

586 behavior is due to shallow $(\leq 40 \mathrm{~cm})$ carbonate formation driven by seasonal precipitation biased 587 to frequent summer rainfall, while deeper $(\geq 40 \mathrm{~cm})$ carbonates reflect formation after large, 588 infrequent, and discrete mid-summer rainstorms.

\section{Acknowledgements}

591 We thank Almendra Brasca and Villavicencio, Divisadero Largo, and Nacuñan Nature Reserve 592 park rangers for generous field assistance, and Andy Schauer and Kyle Samek for lab assistance 593 at the University of Washington Isolab. This work was funded by a National Science Foundation 594 grant 1251966 awarded to GDH. 


\section{References}

Affek, H.P. and Eiler, J.M., 2006. Abundance of mass $47 \mathrm{CO}_{2}$ in urban air, car exhaust, and human breath. Geochimica et Cosmochimica Acta, v. 70, p. 1-12.

Amundson, R., Wang, Y., Chadwick, O., Trumbore, S., McFadden, L., McDonald, E., Wells, S., and DeNiro, M., 1993. Factors and processes governing the ${ }^{14} \mathrm{C}$ content of carbonate in desert soils. Earth and Planetary Science Letters, v. 125, p. 385-405.

Birkeland, P.W., 1999. Soils and Geomorphology. New York, Oxford University Press, 430 p.

Breecker, D.O., Sharp, Z.D., and McFadden, L.D., 2009. Seasonal bias in the formation and stable isotopic composition of pedogenic carbonate in modern soils from central New Mexico, USA. Geological Society of America Bulletin, v. 121, no. 3-4, p. 630-640.

Caravagno, J.N., 1988. Distribution of $\mathrm{C}_{3}$ and $\mathrm{C}_{4}$ grasses at different altitudes in a temperate arid region of Argentina. Oecologia, v. 76, p. 273-277.

Cerling, T.E., and Quade, J., 1993. Stable carbon and oxygen isotopes in soil carbonates, in Swart, P.K., Lohmann, K.C., McKenzie, J., and Savin, S.M., editors, Climate change in continental isotopic records, Geophysical Monograph: Washington D.C., American Geophysical Union, p. 217-231.

Dennis, K.J., Affek, H.P., Passey, B.H., Schrag, D.P., and Eiler, J.M., 2011. Defining an absolute reference frame for 'clumped' isotope studies of $\mathrm{CO}_{2}$. Geochimica et Cosmochimica Acta, v. 75, p. $7117-7131$.

Drever, J.I., 1982. The geochemistry of natural waters. New York, Prentice Hall, 436p.

Eiler, J.M., 2007. "Clumped-isotope" geochemistry-- The study of naturally-occurring, multiply substituted isotopologues. Earth and Planetary Science Letters, v. 262, p. 209-327. 
617 Eiler, J.M., and Schauble, E., 2004. ${ }^{18} \mathrm{O}^{13} \mathrm{C}^{16} \mathrm{O}$ in Earth's atmosphere. Geochimica et Cosmochimica Acta, v. 68, p. 4767-4777.

619 Friedman, I., and O'Neil, J.R., 1977. Compilation of stable isotope fractionation factors of 620 geochemical interest. v. 400. US. GPO.

621 Gabitov, R.I., Watson, E.B., and Sadekov, A., 2012. Oxygen isotope fractionation between calcite and fluid as a function of growth rate and temperature: An in situ study. Chemical

624 Guevara, A., Giodano, C.V., Aranibar, J.N., Quiroga, M., Villagra, P.E., 2010. Phenotypic 625 plasticity of the coarse root system of Prosopsis flexuosa, a phreatophyte tree, in the Monte Desert (Argentina). Plant and Soil, v. 330, p. 447-464.

627 Ghosh, P., Adkins, J., Affek, H., Balta, B., Guo, Wl., Schauble, E.A., Schrag, D., and Eiler, J.M., 628 2006. ${ }^{13} \mathrm{C}-{ }^{18} \mathrm{O}$ bonds in carbonate minerals: A new kind of paleothermometer. Geochimica et Cosmochimica Acta, v. 70, p. 1430-1456.

630 Geology, v. 306-307, p. 92-102.

Ghosh, P., Garzione, C.N., and Eiler, J.M., 2006. Rapid uplift of the Altiplano revealed through ${ }^{13} \mathrm{C}-{ }^{18} \mathrm{O}$ bonds in paleosol carbonates. Science, v. 311, p. 511-515.

Gil, A.F., Villalba, R., Ugan, A., Cortegoso, V., Neme, G., Michieli, C.T., Novellino, P., and Durán, V., 2014. Isotopic evidence on human bone for declining maize consumption during the little ice age in central western Argentina. Journal of Archaeological Science, v. 49 , p. 213-227.

Gile, L.H., Peterson, F.F., and Grossman, R.B., 1966. Morphological and genetic sequences of carbonate accumulation in desert soils. Soil Science, v. 101, no. 5, p. 347-360. 
Giordano, C., Guevara, A., Boccalandro, H., Sartor, C., Villagra, P.E., 2011. Water status, drought responses, and growth of P. flexuosa trees with different access to the water table in a warm South American desert. Plant Ecology, v. 212, p. 1123-1134.

Guo, W., 2008. Carbonate clumped isotope thermometry: application to carbonaceous chondrites and effects of kinetic isotope fractionation. Dissertation, California Institute of Technology.

Hamdi-Aissa, B., Valles, V., Aventurier, A., and Ribolzi, O., 2004. Soils and brine geocheistry and mineralogy of hyperarid desert playa, Ouargla Basin, Algerian Sahara. Arid Land Research and Management, v. 18, p. 103-126.

Hoke, G.D., Aranibar, J.N., Viale, M., Araneo, D.C., and Llano, C., 2013. Seasonal moisture sources and the isotopic composition of precipitation, rivers, and carbonates across the Andes at $32.5-35.5{ }^{\circ}$ S. Geochemistry, Geophysics, Geosystems, v. 14, p. 962-978.

Hoke, G.D., Garzione, C.N., Araneo, D.C., Latorre, C., Strecker, M.R., and Williams, K.J., 2009. The stable isotope altimeter: do quaternary pedogenic carbonates predict modern elevations? Geology, v. 37, p. 1015-1018.

Hough, C.G., Fan, M., and Passey, B.H., 2013. Calibration of the clumped isotope geothermometer in soil carbonate in Wyoming and Nebraska, USA: Implications for paleoelevation and paleoclimate reconstruction. Earth and Planetary Science Letters, v. 391, p. 110-120.

Huntington, K.W., Eiler, J.M., Affek, H.P., Guo, W., Bonifacie, M., Yeung, L.Y., Thiagarajan, N., Passey, B., Tripati, A., Daeron, M., and Came, R., 2009. Methods and limitation of 'clumped' CO2 isotope (D47) analysis by gas-source isotope ratio mass spectrometry. Journal Mass Spectrometry, v. 44, p. 1318-1329. 
661 Huxman, T.E., Snyder, K.A., Tissue, D., Leffler, A.J., Ogle, K., Pockman, W.T., Sandquist,

662

663

664

665

666

667

668

669

670

671

672

673

674

675

676

677

678

679

680

681

682

D.R., Potts, D.L., and Schwinning, S., 2004. Precipitation pulses and carbon fluxes in semiarid and arid ecosystems. Oecologia, v. 141, p. 254-268.

Hyland, E.G., and Sheldon, N.D., 2013. Coupled $\mathrm{CO}_{2}$-climate response during the Early Eocene Climatic Optimum. Paleogeography, Paleoclimatology, Paleoecology, v. 369, p. 125-135.

Hyland, E.G., Sheldon, N.D., Van der Voo, R., Badgley, C., and Abrajevitch, A., 2015. A new paleoprecipitation proxy based on soil magnetic properties: Implications for expanding paleoclimatology reconstructions. Geological Society of America Bulletin, doi:10.1130/B31207.1.

Inskeep, W.P., and Bloom, P.R., 1986. Calcium carbonate supersaturation in soil solutions of Calciaquolls. Soil Science of America Journal, v. 50, p. 1431-1437.

Jobbagy, E.G. and Jackson, R.B., 2001. The distribution of soil nutrients with depth: Global patterns and the imprint of plants. Biogeochemistry, v. 53, p. 51-77.

Kim, S., and O'Neil, J.R., 1997. Equilibrium and nonequilibrium oxygen isotope effects in synthetic carbonates. Geochimica et Cosmochimica Acta, v. 61, p. 3461-3475.

Kluge, T., John, C.M., Jourdan, A., Davis, S., and Crawshaw, J., 2015. Laboratory calibration of the calcium carbonate clumped isotope thermometer in the $25-250{ }^{\circ} \mathrm{C}$ temperature range. Geochimica et Cosmochimica Acta, v. 157, p. 213-227.

Labraga, J.C., and Villalba, R., 2008. Climate in the Monte Desert: Past trends, present conditions, and future projections. Journal of Arid Environments, v. 73, p. 154-163.

Lisiecki, L. E., Raymo, M. E., 2005. A Pliocene-Pleistocene stack of 57 globally distributed benthic d180 records. Paleoceanography, v. 20, PA1003, doi:10.1029/2004PA001071. 
Liu, X.Z., Wan, S.Q., Su, B., Hui, D.F., and Luo, Y.Q., 2002. Response of soil $\mathrm{CO}_{2}$ efflux to water manipulation in a tallgrass prairie ecosystem. Plant and Soil, v. 240, p. 213-223.

Luo, Y., and Zhou, X., 2006. Soil Respiration and the Environment. Burlington: Academic Press.

Machette, M. N., 1985. Calcic soils of the southwestern United States. Geological Society of America Special Papers, v. 203, p. 1-22.

Marion, G.M., Verburg, P.S.J., Stevenson, B., and Arnone, J.A., 2008. Soluble element distributions in a Mojave desert soil. Soil Science Society of America Journal,v.72, p.1-9.

Meglioli, P.A., Villagra, P.E., Aranibar, J.N., 2015, in press. Does land use change alter water and nutrient dynamics of phreatophytic trees in the Central Monte desert? Ecohydrology, DOI: $10.1002 /$ eco.1670.

Meyer, N.A., Breecker, D.O., Young, M.H., Litvak, M.E., 2014. Simulating the effect of vegetation in formation of pedogenic carbonate. Pedology, Soil Science Society of America Journal, v. 78, p. 914-924.

Ojeda, R.A., Campos, C.M., Gonnet, J.M., Borghi, C.E., and Roig, V.G., 1998. The MaB Reserve of Nacuñán, Argentina: its role in understanding the Monte Desert biome. Journal of Arid Environments, v.39, p. 299-313.

Passey, B.H. and Henkes, G.A., 2012. Carbonate clumped isotope bond reordering and geospeedometry. Earth and Planetary Science Letters, v. 351-352, p. 223-236.

Passey, B.H., Levin, N.E., Cerling, T.E., Brown, F.H., Eiler, J.M., and Turekian, K.K., 2010. High-temperature environments of human evolution in East Africa based on bond ordering in paleosol carbonates. Proceedings of the National Academy of Sciences of the United States of America, v. 107, p. 11245-11249. 
Peters, N.A., Huntington, K.W., and Hoke, G.D., 2013. Hot or not? Impact of seasonally variable soil carbonate formation on paleotemperature and O-isotope records from clumped isotope thermometry. Earth and Planetary Science Letters. http://dx.doi.org/10.1016/j.epsl.2012.10.024

Plummer, L.N. and Busenberg, E., 1982. The solubilities of calcite, aragonite and vaterite in $\mathrm{CO}_{2}-\mathrm{H}_{2} \mathrm{O}$ solutions between 0 and $90^{\circ} \mathrm{C}$, and an evaluation of the aqueous model for the system $\mathrm{CaCO}_{3}-\mathrm{CO}_{2}-\mathrm{H}_{2} \mathrm{O}$. Geochimica et Cosmochimica Acta, v. 46, p. 1011-1040.

Retallack, G.J., 1994. The environmental factor approach to the interpretation of paleosols. In: Amundson, R., Harden, J., and Singer, M. (Eds.), Factors of Soil Formation: A Fiftieth Anniversary Retrospective Soil Science Society of America Special Publication.

Retallack, G.J., 2005. Pedogenic carbonate proxies for amount and seasonality of precipitation in paleosols. Geology, v. 33, p. 333-336.

Rossi, B.E., and Villagra, P.E., 2003. Effects of Prosopis flexuosa on soil properties and the spatial pattern of understorey species in arid Argentina. Journal of Vegetation Science, v. 14 , p. 543-550.

Rossi, B.E., 2004. Flora y vegetación de la Reserva de Biosfera de Nacuñán después de 25 años de clausura. Ph.D. thesis. la Universidad Nacional de Córdoba, Córdoba, Argentina.

Royer, D.L., 1999. Depth to pedogenic carbonate horizon as a paleoprecipiation indicator? Geology, v. 27, p. 1123-1126.

Quade, J., Garzione, C., and Eiler, J., 2007. Paleoelevation reconstruction using pedogenic carbonates. Reviews in Mineralogy and Geochemistry, v. 66, p. 53-87.

Quade, J., Eiler, J., Daeron, M., Achyuthan, H., 2013. The clumped isotope geothermometer in soil and paleosol carbonate. Geochimica et Cosmochimica Acta, v. 105, p. 92-107. 
728 Schmidt, S., Hetzel, R., Mingoance, F., Ramos, V., 2011. Coseismic displacements and 729 Holocene slip rates for two active thrust faults at the mountain front of the Andean $730 \quad$ Precordillera $\left(\sim 33^{\circ} \mathrm{S}\right)$. Tectonics, v. 30, TC5011.

731 Silva, L.C.R., Giorgis, M.A., Anand, M., Enrico, L., Pérez-Harguineguy, N., Falczuk, V., 732 Tieszen, L.L., and Cabido, M., 2011. Plant and Soil, v. 349, p. 261-279.

733 Tobin, T.S., Schauer, A.J., and Lewarch, E., 2011. Alteration of micromilled carbonate $\delta^{18} \mathrm{O}$ 734 during Kiel Device analysis. Rapid Communications in Mass Spectrometry, v. 25, p. $735 \quad 2149-2152$.

736 Villagra, P.E., Giordano, C., Alvarez, J.A., Cavagnaro, J.B., Guevara, A., Sartor, C., Passera, C., 737 Greco, S., 2011. Ser planta en el desierto: estrategias de uso de agua y resistencia al estrés 738 hídrico en el Monte Central de Argentina. Ecología Austral, v. 21, p. 29-42.

739 Yang, W., Amundson, R., and Trumbore, S., 1994. A model for soil ${ }^{14} \mathrm{CO}_{2}$ and its implications 740 for using ${ }^{14} \mathrm{C}$ to date pedogenic carbonate. Geochimica et Cosmochimica Acta, v. 58, p. $741 \quad 393-399$.

742 Zaarur, S., Affek, H.P., and Brandon, M.T., 2013. A revised calibration of the clumped isotope 743 thermometer. Earth and Planetary Science Letters, v. 382, p. 47-57. 